\title{
What Happens to the Careers of European Workers When Immigrants "Take Their Jobs"?
}

\author{
Cristina Cattaneo \\ Carlo V. Fiorio \\ Giovanni Peri
}

\begin{abstract}
Following a representative longitudinal sample of native European residents over the period 1995-2001, we identify the effect of the inflows of immigrants on natives' career, employment, and wages. We control for individual, country-year, occupation group-year, and occupation group-country heterogeneity and shocks, and construct an imputed inflow of the foreignborn population that is exogenous to local demand shocks. We find that native European workers are more likely to move to occupations associated with higher skills and status when a larger number of immigrants enters their labor market. We find no evidence of an increase in their probability of becoming unemployed.
\end{abstract}

\section{Introduction}

There is debate on the effect that immigrants have on the labor market opportunities of natives (Borjas 2003; Borjas, Grogger, and Hanson 2008; Card 2001, 2009; Card and DiNardo 2000; Ottaviano and Peri 2012). As immigrants concentrate their labor supply in some occupations, their effect on natives depends on how much these occupations compete with, or instead complement, natives' jobs. The effect also

Cristina Cattaneo is senior researcher at Fondazione Eni Enrico Mattei-FEEM, Milan, Italy. Carlo V. Fiorio is an associate professor of public economics at the Department of Economics, Management and Quantitative Methods, University of Milan, Senior researcher at Irvapp, Trento and Research Fellow at Dondena, Milan, Italy. Giovanni Peri is full professor of economics at the Department of Economics, University of California, Davis, U.S.A. The authors thank two anonymous referees for helpful comments and the Fondazione Rodolfo Debenedetti for its support. Participants to the CReAM Immigration conference (London), MILLS Workshop (Milan), and the European Economic Association Meetings (Gothenburg) also provided useful suggestions. This paper was partly funded within the EC project "Sustainable Development in a Diverse World," VI Framework Program. The data used in this article may be acquired from the Eurostat and from IPUMS-International. The authors are willing to advise other scholars on the application process.

[Submitted March 2013; accepted April 2014]

ISSN 0022-166X E-ISSN 1548-8004 (C) 2015 by the Board of Regents of the University of Wisconsin System

THE JOURNAL OF HUMAN RESOURCES • 50 • 3 
depends on the response of natives to immigration as they may change their occupation to take advantage of their specific skills vis-a-vis immigrants (Peri and Sparber 2009, D'Amuri and Peri 2014).

The literature has so far mainly analyzed the aggregate effects of immigration using the regional or national wages and employment of natives (or groups of natives) as outcomes. Researchers have constructed average wages or employment rates for region/skill groups and estimated the impact of immigration on the average outcomes in the group, constructed using repeated cross-sections of individuals. Most of these studies find small wage and employment effects of immigration on natives both in Europe (Dustmann, Frattini, and Preston 2013; D'Amuri, Ottaviano, and Peri 2010; Glitz 2012) and in the United States (Ottaviano and Peri 2012; Card 2009). There are, however, some significant exceptions (Borjas 2003, 2006). A problem of this approach is that labor markets are in continuous flux. People enter and exit labor markets as well as skill groups. This alters the composition of individuals over time in the market (cell) so that the wage effects of immigration identified at that level can be due to changes in wages of individuals or to changes in the composition of individuals in the analyzed cell. In particular, the average outcome of a labor market cell may change because of entry and exit of different workers or because of a change in outcome of incumbent workers. The aggregate analysis can mask differentiated effects of immigration on the incumbents or on the selection of potential entrants and those who exit.

Our analysis asks the less-explored question: How much does immigration affect the occupation and wage of an incumbent native if one follows him/her over time after a significant inflow of immigrants? What happens to native workers over the following years when immigrants take jobs in the same labor market as theirs? This is a very important complement to the aggregate question as it focuses on incumbents and their individual effects. By comparing similar workers, some of whom were exposed to large inflows of immigrants and others who were not, and following them over time, we analyze how competition and complementarity with immigrants affected their careers.

This way of analyzing the effects of immigrants has interesting implications. First, we can control for heterogeneity at the individual level, reducing the scope for omitted variable bias. Second, this method is closer to the idea of evaluating the gain/losses for incumbent native workers when exposed to immigrant competition. Third, it moves the literature on labor market effects of immigration closer to the analysis of individual effects of aggregate shocks (globalization, technology). To the best of our knowledge, this is one of the first papers analyzing the effects of immigration on individual labor market outcomes, following people over time. ${ }^{1}$

The data requirements to implement this type of analysis are larger than those needed for repeated cross-section cell-based regressions. We need longitudinal panel data for a representative sample of native individuals. The data must include demographic and labor market information and provide their location. Further, the data should capture a country (or an economy) during a period in which it received a significant inflow of immigrants. At the same time, we need an aggregate data set to

1. A recent working paper by Kerr and Kerr (2013) looks at STEM (science, technology, engineering, and math) workers' transitions from firms that experience a large increase in foreign skilled workers in the United States. Similarly, a working paper by Foged and Peri (2013) analyzes individual transitions of workers in Denmark. 
construct accurate measures of the local immigration flows for the receiving labor markets. The European Community Household Panel (ECHP) provides a representative longitudinal sample of natives for one of the largest economies in the world: the European Union. The ECHP is a European survey that was designed to provide a representative and cross-nationally consistent picture of households and individuals on a range of topics including income, health, education, housing, demographics, and employment characteristics. The survey, designed as a longitudinal panel, was conducted between 1994 and 2001 in eight successive waves in the EU-15 European countries using a standardized methodology. The ECHP was designed to be representative for native households. Hence, while we use this survey to track the outcomes of natives, we use the harmonized European Labour Force Survey (ELFS) to compute the share of immigrant population by country, year, and occupation group. The ELFS is a larger database and is representative of the whole population in EU countries. It is, however, a repeated cross-section.

We consider individual outcomes and labor-market immigration shocks so that the reverse causality issues are reduced. However, the inflow of immigrants in country/occupation cells may be correlated with unobserved economic and labor market shocks that may affect native careers causing an omitted variable bias. In order to estimate the casual impact of immigrants on individual outcomes, we use an instrumental variable approach. The method is a variation on the so-called "enclave" instrument first used by Altonji and Card (1991), followed by Card (2001), Peri and Sparber (2009), and Lewis (2011) (among others), and now broadly used in this literature. We construct the imputed inflow of immigrants allocating the aggregate flows by country of origin between 1991 and 2001 in proportion to the 1991 immigrant distribution across countries and occupations. We then use these imputed flows as an instrument for actual immigrant flows. This instrument uses the historical location of immigrants and aggregate immigration shocks to predict country-occupation specific immigration. We will discuss further the advantages and the caveats for this identification approach.

This paper focuses on the effect of immigration on natives, who in this paper are defined as persons born in the specific country. ${ }^{2}$ There are four main findings.

First, an inflow of immigrants generates a higher probability that a native worker moves to a higher occupational level within the next year. The effect is statistically and economically significant. We find this result by first grouping occupations in four levels (or "tiers") that are ranked in terms of wage, education, and social status, from lower to higher: "Elementary," "Clerical and Craft," "Technical and Associate," and "Professional and Manager." Hence, we estimate that an increase of immigrants by one percentage point of employment in the occupation-cell increases the probability for a native worker to move to a higher ranked tier by 0.38 percentage points. As the average probability of an annual upgrade to a higher occupational tier for a native worker is 8.8 percentage points, increasing the immigrant share in a cell by four percentage points of employment (its standard deviation in the sample) would increase the probability of upward mobility by 1.5 percentage points. This is a 17 percent increase over the average. Second, we find that in response to immigration there is no change in the probability that a native worker joins unemployment in any of

2. We cannot infer existing immigrants' responses to new immigrants as our individual panel is representative of native population only. 
the following three years. Third, we also find some evidence that immigration increases wages of natives, with some lags (one to two years). The immediate upgrade in response to immigration and the delayed wage gain is compatible with an effect of moving natives toward a better career path, still requiring some time to accumulate specific human capital in the new occupation. Results also suggest that natives move away from self-employment in response to immigration, probably because immigrants themselves are more likely to be self-employed. Fourth, workers both in lower and upper tiers are significantly more likely to experience occupational upward mobility as a consequence of immigrant competition though the coefficient is much larger for workers starting at high tiers. All these effects indicate a dynamic response of natives along the occupational dimension, which may benefit natives in the long run. At the very least, the occupational upgrade protects native individuals on average from the potential competition effect of immigrants, which could be detrimental if they stay in the original job.

Overall, it appears that immigrants speed up the transition of natives to higherranked occupations, which are complementary to lower-ranked ones. The rest of the paper is organized as follows. Section II frames the contribution of this paper within the existing literature. In Section III, we present the empirical framework of analysis. Section IV presents the data set and the main variables, and Section V describes our main results. Section VI extends the analysis and performs robustness checks, and Section VII concludes the paper.

\section{Literature Review}

There is a large literature analyzing the effect of immigration on labor market outcome of natives. Studies such as Borjas (2003); Card (2009); Ottaviano and Peri (2012); and Dustmannn, Frattini, and Preston (2013) tackle the issue by defining a production function that determines the productive interactions between immigrant and native labor. In this framework, the variation to the marginal productivity of native labor caused by immigration is captured by changes in aggregate wages. In the presence of rigidities or upward sloped labor supply, it would also cause changes in aggregate employment. Most of the studies use annual (short-run) or decade (longrun) variation in immigrant population (or employment) to identify the effects on average native wages or aggregate employment. The data used in those studies are "pseudopanels," constructed using repeated cross-sections of individuals (obtained from Census or labor force survey) organized in "cells" such as regions, skill, or region/skill groups, and then followed over time. Even papers specifically analyzing the dynamic effect of immigration on natives identify the effects following "cells," rather than individuals, over time. For example, Cohen-Goldner and Paserman (2011) distinguish between the short-run and medium-run effects of immigrants on wages and employment, taking into account possible labor market adjustments induced by immigration. However, they follow arrival cohorts over time rather than individuals. Peri and Sparber (2009) and D'Amuri and Peri (2014) focus on the "dynamic response" of natives by analyzing whether natives move to more complex jobs as a consequence of immigration. Again, these papers do not follow individuals over time but they use skill cells as units of observation. 
The immigration literature has not, to the best of our knowledge, used individual panel data to measure the effects on natives. Individual panel data allow us to follow individuals during and after immigrants move into their country/occupation and to analyze the impact on their labor market outcomes over one or more years. Peri and Sparber (2011) analyze the substitutability of highly educated natives and foreigners by tracking natives' occupations at two points in time. They then assess how an inflow of immigrant workers with graduate degrees affects the occupation of highly educated natives. In their paper, however, only yearly changes in occupation are recorded and no medium-run effects are considered.

The use of individual panel data to track the medium- and long-run transition has been confined to the analysis of other types of shocks. For instance, Von Wachter, Song, and Manchester (2007); Neal (1995); and Stevens (1997) (among others) analyzed the impact of mass layoffs on employment and wages of individuals who were subject to those shocks by following them for years after the mass layoffs. Oreopulos, von Wachter, and Heisz (2012) analyzed the medium- and long-run effects of a recession at the beginning of one's career. Bartel and Sicherman (1998) studied the effect of technological change on employee training. Zoghi and Pabilonia (2007) analyzed the effect of the introduction of computers on individual wages. Dunne et al. (2004), using establishment-level data, assessed the effect of computer investment on the dispersion of wages and productivity. All of these papers consider aggregate shocks and track their effects on individual panel data. Although this is common in the labor literature, it is rarely done when analyzing the long-run impact of immigration.

The present paper brings individual panel data and a strategy similar to the one used to identify the effects of recession, layoffs, and technological change to the study of the impact of immigration on native workers' labor market outcomes. This is particularly important if natives respond to immigration by changing their specialization (as suggested in Peri and Sparber 2009), or by investing in firms' specific skills (as suggested by the wage dynamics in Cohen-Goldman and Paserman 2011), or by undertaking other changes. These responses, in fact, may take some time to manifest.

\section{Empirical Framework and Implementation}

Let us begin by presenting the empirical framework that we adopt in our analysis. We also discuss in this section important issues related to the identification strategy and to the construction of the instruments.

\section{A. Basic Specification}

Our basic specification relates the presence of immigrants working in the same occupationcountry-year cell of natives to several outcomes of native individuals. In particular, we define $f_{\text {jct }}$ as the number of foreign-born workers in occupation $j$ and country $c$ and year $t$ relative to total workers in that cell. The immigrant inflows are matched to the individual observations by occupation-country-year. Denoting $y_{i t}$ a specific outcome for individual $i$ at time $t$, we estimate the following specification:

$$
y_{i, t}=\phi_{t}+\phi_{l, c}+\phi_{c, t}+\phi_{l, t}+\delta X_{i, t}+\beta f_{j, c, t}+\varepsilon_{i, t}
$$




\section{Table 1}

The Skill Content of Occupations

\begin{tabular}{|c|c|}
\hline Occupation Levels or Tiers & Occupation (ISCO Code-1 Digit) \\
\hline First: "elementary occupations" & 9. Elementary occupations \\
\hline \multirow{5}{*}{$\begin{array}{l}\text { Second: "clerical and craft } \\
\text { occupations" }\end{array}$} & 4. Clerks \\
\hline & $\begin{array}{l}\text { 5. Service workers and shop and market sales } \\
\text { workers }\end{array}$ \\
\hline & 6. Skilled agricultural and fishery workers \\
\hline & 7. Craft and related trades workers \\
\hline & 8. Plant and machine operators and assemblers \\
\hline $\begin{array}{l}\text { Third: "technical and associate } \\
\text { professionals" }\end{array}$ & 3. Technicians and associate professionals \\
\hline $\begin{array}{l}\text { Fourth: "professional and } \\
\text { manager" }\end{array}$ & $\begin{array}{l}\text { 1. Legislators, senior officials, and managers } \\
\text { 2. Professionals }\end{array}$ \\
\hline
\end{tabular}

In Specification 1, the outcome $y$ will be, alternatively, a variable measuring the occupational mobility (or the occupational attainment) of a worker, a dummy for unemployment status, the logarithm of income, or a dummy for self-employment status. The term $\phi_{t}$ is a set of year effects, which controls for common time effects. $\phi_{l, c}$ is a set of occupational-level $(l)$ by country $(c)$ fixed effects, which captures country-specific heterogeneity in relative demand. Occupational-level (or "tier") $l$ is the aggregation of occupations $j$ allowing a ranking of occupations from lower to higher (more on this in Section IV below) as follows: "Elementary," "Clerical and Craft," "Technical and Associate," and "Professional and Manager" (see Table 1). We include all the possible pair-wise interactions between country $c$, year $t$, and occupational-level $l\left(\phi_{c, t}, \phi_{l, t}, \phi_{l, c}\right.$ ). ${ }^{3}$ These fixed effects capture country-specific financial and macroeconomic shocks, occupation-level demand shocks, and the potential heterogeneity of demand and immigration across country and occupation levels. Their inclusion brings the identification based on this approach close to that of national-level studies (such as Borjas 2003, Ottaviano and Peri 2012). In those studies, once the authors have controlled for fixed effects, the remaining variation of immigrants in a cell is assumed to be driven by supply shocks and OLS estimation is applied. We instead worry about potential lingering country-occupation specific demand shocks, and we devise an instrument (described below) based on a shift-share approach at the European level. Finally, we also included the term $\varphi_{i}$, capturing a set of individual fixed effects fully controlling for the individual heterogeneity in all specifications but those measuring occupational mobility, which is an outcome already defined as a difference over time for one individual.

Given the longitudinal structure of our data set, we also estimate a specification that includes lags of the immigrant share in order to see whether some effects of immigration on native workers occur with a lag:

3. We do not include specific occupation (nine groups) fixed effects and their interactions as all our occupational mobility and occupational attainment variables are defined for occupational levels, which allow for a clear ranking of occupations. 
(2) $y_{i, t}=\phi_{t}+\phi_{l, c}+\phi_{c, t}+\phi_{l, t}+\delta X_{i, t}+\sum_{r=0}^{R} \beta_{r} f_{j, c, t-r}+\varepsilon_{i, t}$.

The first outcome that we consider is an indicator of occupational mobility. Our data have a definition of occupations that can be organized (as we illustrate in the next section) into four tiers (or levels) with a clear ranking. These tiers are associated with different levels of wage, average education, and use of cognitive and complex skills. Ranking those tiers with respect to any of those variables would provide the same ordering. Our occupational mobility variable is a standardized index that takes the value of 0 if at time $t$ the individual $i$ works in the initial occupational level (the occupation the individual was employed in when he/she entered the sample) $)^{4}$ while it takes a value of +1 if he/she works in a higher tier one, or -1 if he/she works in a lower ranked one. This variable, therefore, is an "index of occupational mobility" relative to the entry level. Based on this variable, we also created a dummy "upgrade occupational mobility" index and a "downgrade occupational mobility" dummy, which isolate upward and downward mobility respectively, allowing for differential effects of immigrants on either side ("up" or "down") of occupational mobility. We also consider a measure of occupational attainment, which reports the tier level $(l)$ of individual $i$ at year $t$ and hence captures the absolute position of a worker in the occupational tiers.

The second outcome that we consider is the worker's unemployment status. The outcome variable is a dummy equal to 1 if individual $i$ is unemployed at time $t$ and 0 if he/she is not. The third is the logarithmic income for individual $i$ at time $t$, distinguishing between yearly wage-salary earnings and yearly self-employment income. Finally, we consider an indicator that records entrepreneurial activity computed as a dummy equal to 1 if an employed person receives only wage and salary and no selfemployment income and 0 otherwise.

\section{B. Identification and Instrumental Variable}

The goal of the empirical analysis is to identify and consistently estimate the parameter $\beta$ in Equations 1 and 2 so that it can be interpreted as the causal effect of immigration on individual outcomes. Our immigration variable varies at the countryoccupation-year group and we control with fixed effects for each pair-wise interaction of country, year, and occupational-level. Labor market outcomes could differ across countries due to differences in institutions, sector of specialization, and other structural features. Hence, we control for country-occupation level fixed effects $\left(\phi_{l, c}\right)$. Changes in technology, such as adoption of computers, the progress of information technology, the change in the relative demand across skills, are controlled for by the inclusion of the occupation level by year fixed effects $\left(\phi_{l, t}\right)$. Country-specific shocks driven by political, financial, or institutional evolutions are also controlled for by the inclusion of the country by year fixed effects $\left(\phi_{c, t}\right)$. Finally, the heterogeneity of native individuals is controlled for either by differencing the dependent variable (as in the case of occupational mobility) or by including individual fixed effects $\left(\phi_{i}\right)$. The described fixed effects absorb a large array of demand shocks and have been considered as sufficient controls to identify a causal effect in national-level analysis (Borjas 2003,

4. In case the individual enters the panel as an unemployed or out-of-work person, the initial occupation level is the first one observed in our data. 
Ottaviano and Peri 2012). Still, there can be omitted variables at the country-occupationyear level that cause estimation bias. Specific labor markets, defined as occupationcountry cells, might be experiencing expansion or contraction of their labor demand in a certain year for specific reasons related to the interaction of technological change and specific country conditions. These shocks could affect the inflow of immigrants, as well as individual outcomes for native workers, generating a spurious correlation. Hence, we adopt an instrumental variable strategy. Using the national censuses of 1991, we can observe the distribution of immigrants from nine different areas of origin to European countries and occupational groups. ${ }^{5}$ From the 1991 censuses, we can calculate the total number of foreign born from area of origin $N$ in Europe, $F_{1991}^{N}$. We then impute the share of European immigrants of nationality $N$ who are in country $c$ and occupation $j, s h_{j, c, 1991}^{N}$, as the product of the country $c$ 's share of European immigrants of area of origin $N, F_{c, 1991}^{N} / F_{1991}^{N}$ and the occupation $j$ share of European immigrants of area of origin $N, F_{j, 1991}^{N} / F_{1991}^{N}$, both measured in 1991. So we obtain: $s h_{j, c, 1991}^{N}=\left(F_{c, 1991}^{N} / F_{1991}^{N}\right)\left(F_{j, 1991}^{N} / F_{1991}^{N}\right) .{ }^{6}$ Such initial imputation reduces the risk of endogeneity of immigrant distribution to cell-specific economic conditions for two reasons. First, it uses variables measured in 1991 while the analysis is relative to the period 1995-2001. Second, it assumes independence between the country and occupational distribution of immigrants, preventing country-occupation specific factors in 1991 to affect it. We then use the OECD data on net migrant flows by area of origin into Europe $\left(\Delta F_{t}^{N}\right)$ to obtain the total number of foreign born from each area in each year. In particular, the number of foreign born from area of origin $N$ in Europe in year $t$ is constructed as $\widehat{F_{t}^{N}}=F_{1991}^{N}+\Sigma_{s=1992, \ldots, t} \Delta F_{s}^{N}$. Then we allocate the total number of immigrants from each area of origin to country-occupation cells according to their shares $s h_{j, c, 1991}^{N}$. The "imputed" number of immigrants of area of origin $N$ in occupation $j$ and country $c$ in year $t$ will therefore be: $\widehat{F_{j, c, t}^{N}}=\widehat{F_{t}^{N}} s h_{j, c, 1991}^{N}$. The total imputed number of foreign born in that country-occupation cell is obtained by summing across areas of origin so that $\widehat{F_{j, c, t}}=\Sigma_{N} \widehat{F_{j, c, t}^{N}}$. We then divide this imputed immigrant population in occupation $j$ and country $c$ by the total imputed employment in that cell to obtain $\widehat{f_{j, c, t}}=\left(\widehat{F_{j, c, t}} / \widehat{E m p l} l_{j, c, t}\right)$, where $\widehat{E m p l} l_{j, c, t}$ is an imputed measure of employment, defined as the stock of natives in each country-occupation cell as of 1991, plus the total imputed number of foreign born in that country-occupation cell. We use $\widehat{f_{j, c, t}}$ as instrument for $f_{j, c, t}$, the employment share of foreign born in occupation $j$, country $c$, and period $t$.

The assumption behind this instrument is that the distribution of immigrants of specific nationality across countries or occupations in 1991 is the result of historical settlements and past historical events. This initial distribution, combined with networks of information and individual preferences for their own kind, implies that new immigrants are more likely to move to the same country-occupations in which previous immigrants

5. The areas of origin that we construct are: Central and South America, Eastern Europe, Middle East Central Asia, North Africa, North America, Oceania-Pacific, Other Africa, South and Eastern Asia, Western Europe. 6. An alternative instrument was developed using the distribution of nationality $N$ across occupations in the EU minus the destination country in the formula. Hence $s h_{j c 1991}^{N}=\left(F_{c 1991}^{N} / F_{1991}^{N}\right)\left(F_{j,-c, 1991}^{N} / F_{-c, 1991}^{N}\right)$. This might be motivated by the fact that in Europe in some cases, country-of-origin can be tightly linked to country of destination (for example, Algerians in France), which might argue against the validity of the instrument in this context. The empirical results for this instrument (available upon request) are similar to those presented in the text. 
of the same nationality operated. Hence, in periods of large aggregate immigrants inflows that vary by country of origin, independently of labor market shocks, cells receive different inflows of immigrants due to their initial different composition. The countryoccupation specific changes in demand after 1991 do not affect at all the instrument. Moreover, the rich set of fixed effects captures a large part of demand shocks. Hence, the variation of the instrument, after controlling for the fixed effects, can be thought of as proxying for a supply-driven change in immigrants. It should, therefore, be correlated with the share of foreign born but not with the region-sector specific demand shocks. Let us emphasize again that our approach combines the fixed effects controls used in the "national-level" approach with the imputed immigration instrumental variable used in the area approach. Also, in constructing the instrument $\widehat{f_{j, c, t}}$, we use census data from European countries in 1991 to compute the initial shares and aggregate OECD flows of immigrants to European countries to measure the total flows by nationality. The independent variable, $f_{j, c, t}$, is taken instead from the European Labor Force Survey (as described below), available only between 1995-2001. Hence, using a different, much larger (census) and lagged in time (1991) data set to construct the IV should also reduce the measurement error bias and increase the exogeneity of the IV.

\section{Data and Summary Statistics}

The main data set used is the European Community Household Panel (ECHP), a survey that involves annual interviewing of a representative panel of households and individuals in each EU-15 country. The total duration of the ECHP was eight years, running from 1994 to 2001. In the first wave, a sample of around 60,500 nationally representative households - including approximately 130,000 adults aged 16 years and older - were interviewed in the EU-12 Member States. Austria, Finland, and Sweden (which joined the European Union in 1995) joined the ECHP project in 1995, 1996, and 1997, respectively. Two major areas covered in considerable detail in the ECHP are the economic activity and personal income of the individuals interviewed. Information on other topics such as health, education, housing, demographics, and employment characteristic was also provided.

The important feature of ECHP is its longitudinal panel structure. Within each country, the original sample of households and persons is followed over time at annual intervals. Persons who move or otherwise form or join new households are followed at their new location, provided they move within the same country. In this manner, the sample reflects demographic changes in the population and continues to remain representative of the population over time, except for losses due to sample attrition. Households formed purely of new immigrants into the population are not included (European Commission 1996). Hence, the survey is only representative of natives. Although attrition is a typical problem with panel surveys and ECHP is no exception, its sample dynamic compares well with other similar panels (Peracchi 2002).

While detailed and longitudinal, the ECHP is only a small sample and it is only representative of natives. In order to measure the presence of foreign born as a share of the population, we use the harmonized European Labour Force Survey (ELFS), which groups together country-specific surveys at the European level (see Eurostat 2009). We use only data ranging from 1995 to 2001 since data on place of birth be- 
fore 1995 are absent in most countries. We use ELFS to construct yearly measures of foreign-born shares by occupation and country. The ELFS is an aggregation of repeated cross-sections, built with standard sampling techniques to make them representative of the national labor force, allowing us to capture inflows and outflows of migrants by country and years. The sample size of ELFS is five to ten times larger than the ECHP, depending on the year and country considered, allowing for a more reliable estimate of migrant shares by occupation. Using ELFS, we are left with 11 of the EU-15 countries (namely Austria, Belgium, Denmark, Finland, France, Greece, Ireland, the Netherlands, Spain, Portugal, and the United Kingdom). As for the others, there is no information allowing us to distinguish between native- and foreign-born individuals. $^{7}$

In both data sets, we selected only observations relative to working age individuals (15-65). Their occupations are coded according to the 1988 International Standard Classification of Occupations (ISCO) produced by the International Labour Office (ILO 1990). The ISCO classification is the result of detailed investigation of national coding of occupations in the European countries and organizes them into standard groups (Elias and McKnight 2001). We group the ISCO-88 occupations into four occupational levels or "tiers." Table 1 provides the correspondence between the four occupation tiers and the ISCO occupations at one-digit. The first tier ("Elementary") includes occupations that use skills associated with a basic general education, usually acquired by the completion of compulsory education. Examples of occupations in the first tier include postal workers, hotel porters, cleaners, and catering assistants. The second tier ("Clerical and Craft") covers a large group of occupations, all of which require basic knowledge as for the first tier, but also worker-related training or work experience. Occupations classified at this level include machine operation, driving, caring occupations, retailing, and clerical and secretarial occupations. The third tier ("Technical and Associate") applies to occupations that normally require a body of knowledge associated with a period of post-secondary education but not necessarily up to a college degree level. A number of technical occupations fall into this category, as do a variety of trades occupations and proprietors of small businesses. In the latter case, educational qualifications at subdegree level or a lengthy period of vocational training may not be a necessary prerequisite for competent performance of tasks, but a significant period of work experience is typical. The fourth tier ("Managers and Professionals") relates to what are often termed professional occupations and managerial positions in corporate enterprises or national/local government such as legislators and senior officials and managers. Occupations at this level typically require a tertiary degree or equivalent period of relevant work experience.

Table 2 shows the distribution of native workers across the four tiers. As we notice from Columns 1-2, overall about 8 percent of individual-year observations fall in the first occupation tier, 56 percent in the second tier, 14 percent in the third, and 22 percent in the fourth (top) tier occupations. This table also shows frequencies (Columns $3-4)$ of tiers in terms of individuals rather than individual-years, showing that 14 percent of individuals ever worked in the first tier, 67 percent in the second, 21 percent in the third, and 29 percent in the fourth, for a grand total of 77,410 individual-tier

7. It should be noted that ECHP, besides being unable to provide a representative sample of the foreign population in the EU, lacks information on respondents' country of birth in four out of 15 countries, namely Germany, the Netherlands, Greece, and Luxembourg. 


\section{Table 2}

\section{Distribution of Native Workers in the Four Occupation Tiers (Percent). Average 1995-2001}

\begin{tabular}{|c|c|c|c|c|}
\hline \multirow[b]{3}{*}{$\begin{array}{l}\text { Occupation } \\
\text { Tiers }\end{array}$} & \multicolumn{4}{|c|}{ All Natives } \\
\hline & \multicolumn{2}{|c|}{ By Individual-Years } & \multicolumn{2}{|c|}{ By Individuals } \\
\hline & $\begin{array}{c}\text { Frequence } \\
\text { (1) }\end{array}$ & $\begin{array}{l}\text { Percent } \\
\text { (2) }\end{array}$ & $\begin{array}{c}\text { Frequence } \\
\text { (3) }\end{array}$ & $\begin{array}{c}\text { Percent } \\
\text { (4) }\end{array}$ \\
\hline First & 21,701 & 8.26 & 8,384 & 14.24 \\
\hline Second & 146,173 & 55.64 & 39,197 & 66.58 \\
\hline Third & 36,292 & 13.81 & 12,518 & 21.26 \\
\hline Fourth & 58,545 & 22.28 & 17,311 & 29.41 \\
\hline \multirow[t]{2}{*}{ Total } & 262,711 & 100.00 & 77,410 & 131.50 \\
\hline & & & \multicolumn{2}{|c|}{ (Number of individuals $=58,868)$} \\
\hline
\end{tabular}

Source: authors' calculation based on ECHP data.

Notes: Columns 1 and 2 report statistics by individual-years, summing up to the total sample size. Columns 3 and 4 report frequencies and shares of individual who have ever been of each tier. The total frequency is higher than the number of individuals suggesting that some individuals have been employed in different tiers over the period considered.

observations. Considering that we have about 59,000 individuals in our sample, this table suggests that mobility across occupational tiers is substantial as one quarter of the European individuals in the period considered has held occupations in at least two different tiers.

The grouping of the occupations into the four hierarchical levels is quite reasonable. The aggregate data, in fact, show that moving from Tier 1 to 4 we find an increasing percentage of native workers with tertiary education. The levels of wage and salary earnings also increase and so does income from self-employment. In addition, a higher score in complex skills as well as a lower score in manual skills is associated with higher tiers (see Table A1 in the appendix to see these descriptive statistics). ${ }^{8}$

The full sample of native workers comprises over 260,000 individual-year observations. Table A2 provides summary statistics of the main outcome variables for the full and the 2SLS sample. The latter is restricted to countries for which an instrument can be constructed..$^{9}$ The average of the occupational mobility index in the full sample is 0.03 , which suggests that the upgrades are more likely than downgrades. In fact, about

8. The intensity of skills of the different tiers are computed using the D'Amuri and Peri (2014) calculation based on the O*NET data from the U.S. Department of Labor. Complex scores are computed as the average of scores in communication, complex, and mental skills. Noncomplex, manual scores are the average of scores in manual and routine skills. The higher scores in complex tasks for Tier 4 occupations imply that workers in this group are the most likely to use intensively complex skills compared to the rest of the workers. 9. The sample in the 2SLS estimations does not include all 11 countries available because the 1991 census data used to compute the instrument were available only for six, namely France, United Kingdom, Greece, Spain, Portugal, and Austria. 
10 percent of individual-year observations record an occupation upgrade and about 7 percent a downgrade. The percentages computed for the 2SLS sample are almost the same. A better idea of the intertier mobility is given by the Matrix A3 in the appendix. That table shows that the more likely transition within one year is from Tier 1 to 2: every year, 19 percent of individuals in Tier 1 transition to Tier 2. Also common is transitioning from Tier 3 to 4 (7.3 percent per year). The most common downward transition is from Tier 3 to 2 (8.6 percent of those in Tier 2 experience it within a year). The other transitions are not larger than 5 percent per year. Overall, however, transitions between two adjacent tiers occur to 5-10 percent of individuals in the sample. Looking at worker-year observations (Table A2), the average unemployment rate is around 5 percent and the other averages for the outcome variables are very similar considering the full or the 2SLS samples.

Our main explanatory variable is the share of foreigners employed in country $c$ and time $t$ in occupation $j$. We define as foreign born those workers who were born in a country different from the one where they currently reside. Figure 1 shows the average share (1995-2001) of foreign-born workers in employment by country (left panel) and by the ISCO occupation categories (right panel). The first shows that EU countries widely differed in their share of foreign workers. Averaging the whole period, in France about 10 percent of the working population was foreign born, in Belgium that percentage was over nine, while in Finland it was less than 2 percent of the population. Breaking down the foreign-born population of workers by ISCO codes, one also notices that foreign-born workers are a relatively large share (roughly 10 percent) of workers in elementary occupations but they also constitute a large share (about 6-7 percent) of those employed in occupations requiring high qualifications (such as professional, legislators, senior officials, and managers).

\section{Main Empirical Results}

In this section, we present the results of the empirical analysis. As the main explanatory variable, $f_{j, c, t}$, varies at the occupation-country-year level, and as individuals are followed over time, we use a two-way cluster to compute the standard errors. To account for possible correlation within individual over time, one needs to cluster at the individual level. To account for the correlation within the same occupationcountry-year, one would cluster at that level. Hence, the two-way cluster should account for correlation within each group and across them so that the standard errors are not artificially reduced by within group correlation. The reported regressions include all individual controls $\left(X_{i, t}\right)$, the year effects $\left(\phi_{t}\right)$, and the full set of two-way interaction dummies $\left(\phi_{c, t}, \phi_{l, t}, \phi_{l, c}\right)$. The only coefficients shown in the estimation tables are those on the main explanatory variable, $f_{j, c, t}$.

Table 3 and the other tables up to Table 10 have the following structure for the first four columns. The first column presents OLS estimates using the full sample of 11 countries. In the second column, we restrict the sample to the set of six countries for which we can construct the instrument (driven by the availability of 1991 census microdata). The third column estimates the same specification using 2SLS with the instrument described above. In Specification 4, we include three lags of the immigrant share (explanatory variable) as in Equation 2, with $R=3$. In Tables 3-5 and 9, as the 


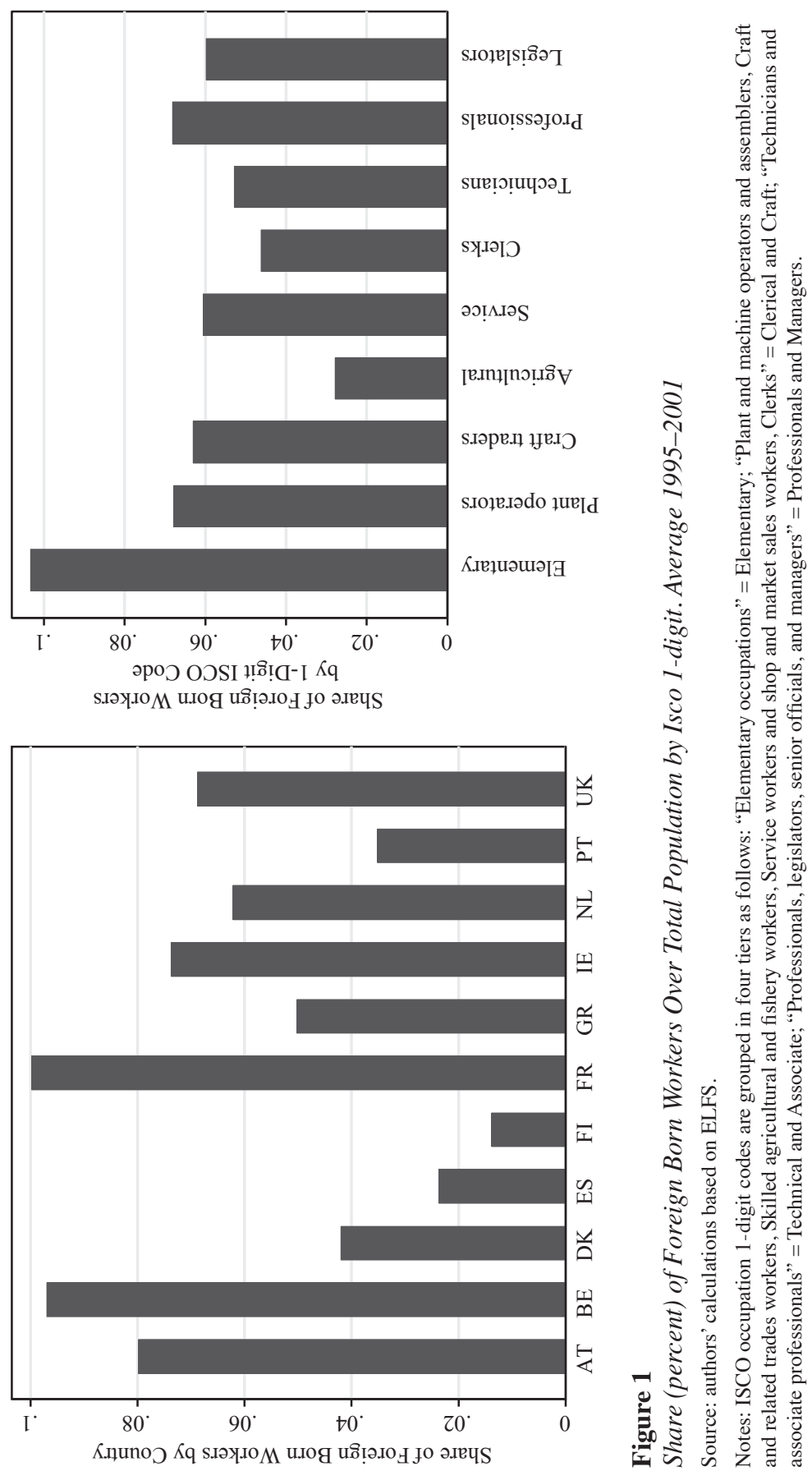


dependent variable is a measure of occupation mobility, it measures a change in time; hence, no individual fixed effects are included. In the other regressions in which outcomes are not differenced, individual fixed effects $\phi_{i}$ are included.

\section{A. Immigrants and Native Job Mobility and Attainment}

In Table 3, we report the estimates of the coefficient on the immigrant share of employment $\left(f_{j, c, t}\right)$ when the dependent variable is the occupational mobility index described above. The outcome $y_{i, t}$ for occupational level is coded with a discrete variable that is standardized to 0 for the occupational tier that the individual had when we first observe her/him in our panel. It takes a value of +1 or -1 if the worker experiences a level upgrade or downgrade, respectively, relative to the initial occupational level. If the individual did not change tier or went back to the original one, the variable takes a value of $0 .{ }^{10}$

The 2SLS results are robust and consistent across specifications. The imputed immigrant share by cell, constructed as described in Section IIIB, turns out to be a strong instrument for the endogenous variable in all the specifications used. The $F$-statistics of the excluded instrument, reported in the last row of the tables, are always well above ten and in many cases very high. The coefficient estimates show that the effect of immigration on occupation level mobility is positive and significant at time $t$ for all specifications. First, let us notice that the OLS estimates are not very different in their size and significance when using the full sample of 11 countries (Specification 1) or the restricted sample of six countries (Specification 2). The comparison of the first two columns, in fact, shows that the estimates are close, suggesting that no large bias is introduced by the smaller sample.

The 2SLS estimates of Column 3, however, are significantly larger than the OLS ones. This direction of the bias suggests that immigrants in Europe might have moved endogenously to occupations or countries that were not experiencing fast upward career mobility for natives. For instance, one may think of a positive demand shock for a particular set of occupations in a particular country. This increase in demand would tend to draw immigrants into that market as well as keep native-born workers from moving out of it although the increase in supply would tend to push workers out. These types of endogenous inflows would bias the estimate toward zero. Our instrument is, by construction, uncorrelated with these types of demand shocks and hence it only allows disentangling the supply push margin. ${ }^{11}$ Finally, measurement error in the ELFS, corrected by the census-based instrument, could also contribute to explain the downward OLS bias.

Focusing on the specification in Column 3, the 2SLS estimated effect of immigrants on occupational level is large and significant. Using the coefficient of 0.7 , an increase of immigrants by one standard deviation of employment in a cell (equal to four percentage points) would increase the average measure of occupational mobility by nearly 0.03 points. This implies that it made an occupational level upgrade three

10. In case the individual enters the panel as a nonemployed person, the initial occupation level refers to the first time we see him/her working. In case an individual temporarily exits employment, we ignore that observation as we would be unable to correctly assign him/her an occupation level. However, the individual is retained in the sample if we observe him/her at least two periods over the period considered as this still could allow us to define occupational mobility indices or introduce individual fixed effect estimation.

11. We thank an anonymous referee for suggesting this example to explain the direction of the bias of the OLS estimates. 


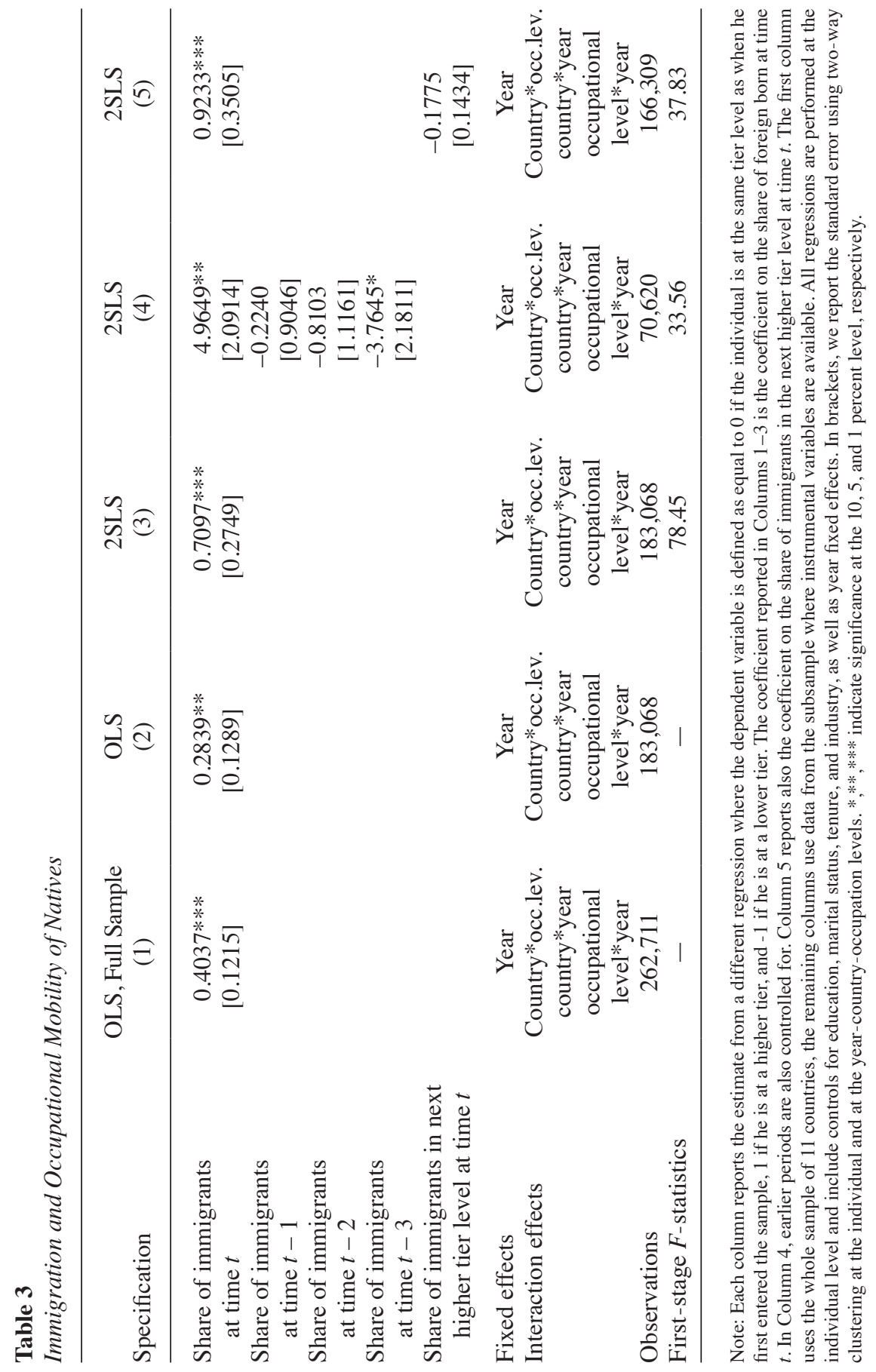


percentage points more likely or an occupational downgrade three percentage points less likely for a native. In Column 4, we include the past values of the share of immigrants. In this specification, both the contemporaneous and the lags of the immigrant shares are instrumented, including the corresponding lags of the imputed shares in the instrument set. In this specification, the coefficient on the share of immigrants at time $t$ increases up to a value of 5 (Column 4). This large impact of the current share of immigrants, however, is dampened by the effect of the past value of the share of immigrants. The coefficient of the three-year lag is negative and statistically significant. In Specification 4, however, the introduction of lags (three of them) and the need to instrument for each one of them, plus the high correlation among current and lagged variables, reduces significantly the joint power of the instrument and the precision of the estimates. We would not attach too much weight to the exact size of the coefficients in Specification 4 and their implied timing because of large standard errors.

To better understand the details of the occupational response of natives, it is useful to separate between upward and downward occupational mobility. In this way, we are able to detect whether immigrants are genuinely providing a "push" to native careers or if they are simply preventing them to "fall" in the occupational levels. To do this, we define an "upward mobility" dummy that is equal to 1 if an individual moves into an occupation level higher than that of his/her first entry in the sample and 0 otherwise. Similarly, we define a "downward mobility" dummy that is coded 1 if an individual moves to an occupation in a lower tier than the initial one and 0 otherwise.

Table 4 presents results on the dummy "upward mobility." The estimated coefficients are consistently positive and significant. Considering the 2SLS estimates without lags shown in Column 3 , the coefficient of the share of immigrants at time $t$ is 0.38 . This suggests that an increase in the share of immigrants by one standard deviation of cell employment raises the average likelihood of occupational upgrading from the average ( 8.8 percentage points) to 10.3 percentage points. This confirms a significant effect of immigrants on native occupational improvements and shows that more than half of the coefficient in Table 3 is due to increased upward mobility. The coefficients of the lagged variables in Column 4 are not statistically significant, and the point estimates are negative. This dynamic response is consistent with the idea that relatively mobile individuals respond relatively quickly to the pressure as immigrants move into the market. It is important to note that it may take some time for the productive consequences of this upgrade to be realized. Wages, as we will see below, respond with a lag. This likely takes place because a change in occupation, although upward, entails an immediate loss of specific human capital. Nevertheless, the relatively high occupational mobility of natives, especially during their early career, may provide opportunities to respond quickly to competition via upgrading opportunities. Hence, by taking jobs at the lower tiers of the occupational distribution, immigrants provide a push and complementarity benefits to faster career upgrades of natives. Over time. this affords a wage increase or at least protects natives from wage competition. On average, native workers seem to take advantage of this by having higher probability of upward mobility within the considered period (1995-2001).

Table 5 shows results for the dummy "lower occupational level." The coefficients suggest a negative and statistically significant effect of the share of immigrants at time $t$ on the likelihood of moving to a lower tier. The effect is no longer significant (in Specification 4) when lags in the share of immigrants are introduced but, as in Table 4, 


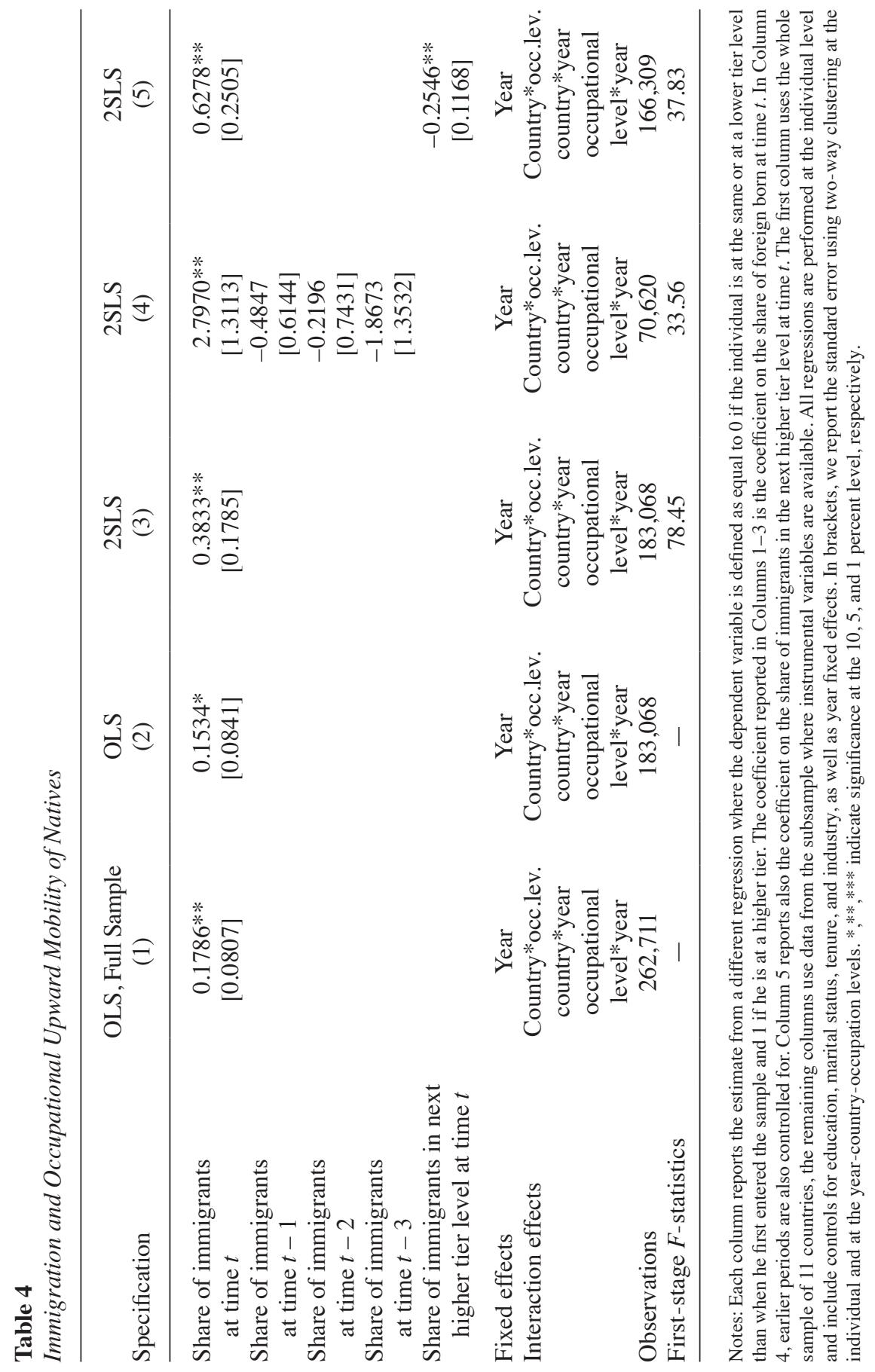




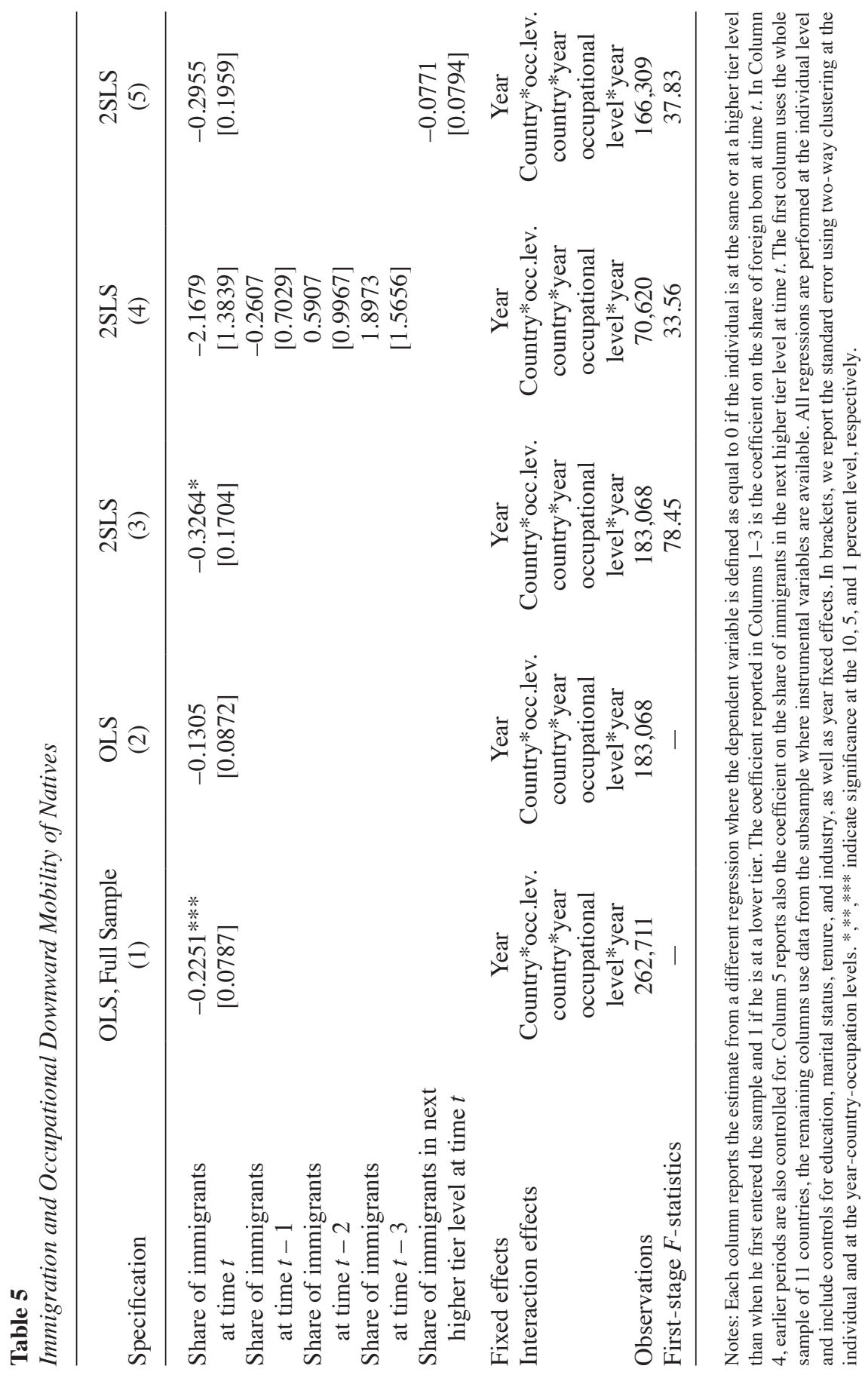


the specification including lags has much larger standard errors because of decreased joint power of the instruments. We can, therefore, summarize that an inflow of immigrants into an occupation-country cell encourages natives to escape competition by significantly increasing the chances of moving to a higher level, but also by somewhat reducing the chances of moving to a lower one. Competition within an occupational level is avoided by moving up the ladder of occupational tiers.

The last columns (Specification 5) of Tables 3, 4, and 5 show another interesting feature of the impact of immigrants on occupational mobility of natives. In those specifications, we also include the share of immigrants in the next higher occupational tier as a control. While increased competition of immigrants within an occupation is escaped by upward mobility, the presence of immigrants in the upper occupational tier could discourage mobility. Natives could encounter competition after upgrading if the next tier up experiences a very large inflow of immigrants. The results show some evidence in favor of this hypothesis. The share of immigrants in the next higher occupation level has a negative and statistically significant effect on the probability of upward mobility (Table 4) while its impact on downward mobility is not significant (Table 5). These results are consistent with the idea that competition in the immediately higher tier may in part discourage upgrading.

Finally, Table 6 shows the main results when the dependent variable is occupational attainment, simply measured as the "occupation level" defined above. In this specification, we include individual fixed effects $\phi_{i}$ in order to account for individual heterogeneity, which in the previous regression was differenced away. The 2SLS coefficients suggest a strong and positive effect of the share of immigrants at time $t$ on the level of occupation of natives. The much larger 2SLS coefficient relative to Table 4 is due to the dependent variable being measured with an index varying between 1 and 4 rather than between 0 and 1 . Converting the effect into standard deviations produces a comparable effect to those estimated above. One standard deviation increase in the share of immigrants would increase the average occupation level by 0.4 , moving the level of attainment from an initial average of 2.4 to 2.8 . This is a 17 percent increase over the average, which is about the same as the probability of upward mobility relative to the average estimated with reference to Table 4. Notice that in Table 6 the downward bias of the OLS is strong enough to produce negative point estimates. The estimates including lagged values of the explanatory variable (Column 4) show some negative coefficients at lags one and two though much smaller in size than the positive contemporaneous one. However, as already noted, the need to instrument for each lag largely reduces the $F$-statistic of the first stage.

These results, taken together, imply that immigration promotes a response of natives in terms of occupational career. By filling occupations at the "manual and routine" end of the occupational spectrum, many immigrants generate opportunities (and increase demand) for jobs in higher occupational tiers that can be filled by natives. Native workers appear to take advantage of these opportunities. These dynamics were found in aggregate by some previous studies (such as Peri and Sparber 2009, D'Amuri and Peri 2014). By considering individual data, however, our analysis shows that individual workers are pushed, on average, to climb the ladder of occupational opportunities more rapidly when immigration into their occupation is larger. Natives are more likely to advance and less likely to drop in their progression from simpler and less paid jobs to more complex and better paid jobs. By following individual native workers, we learn that the higher concentration of natives in higher-ranked occupations in response to immigration is not 


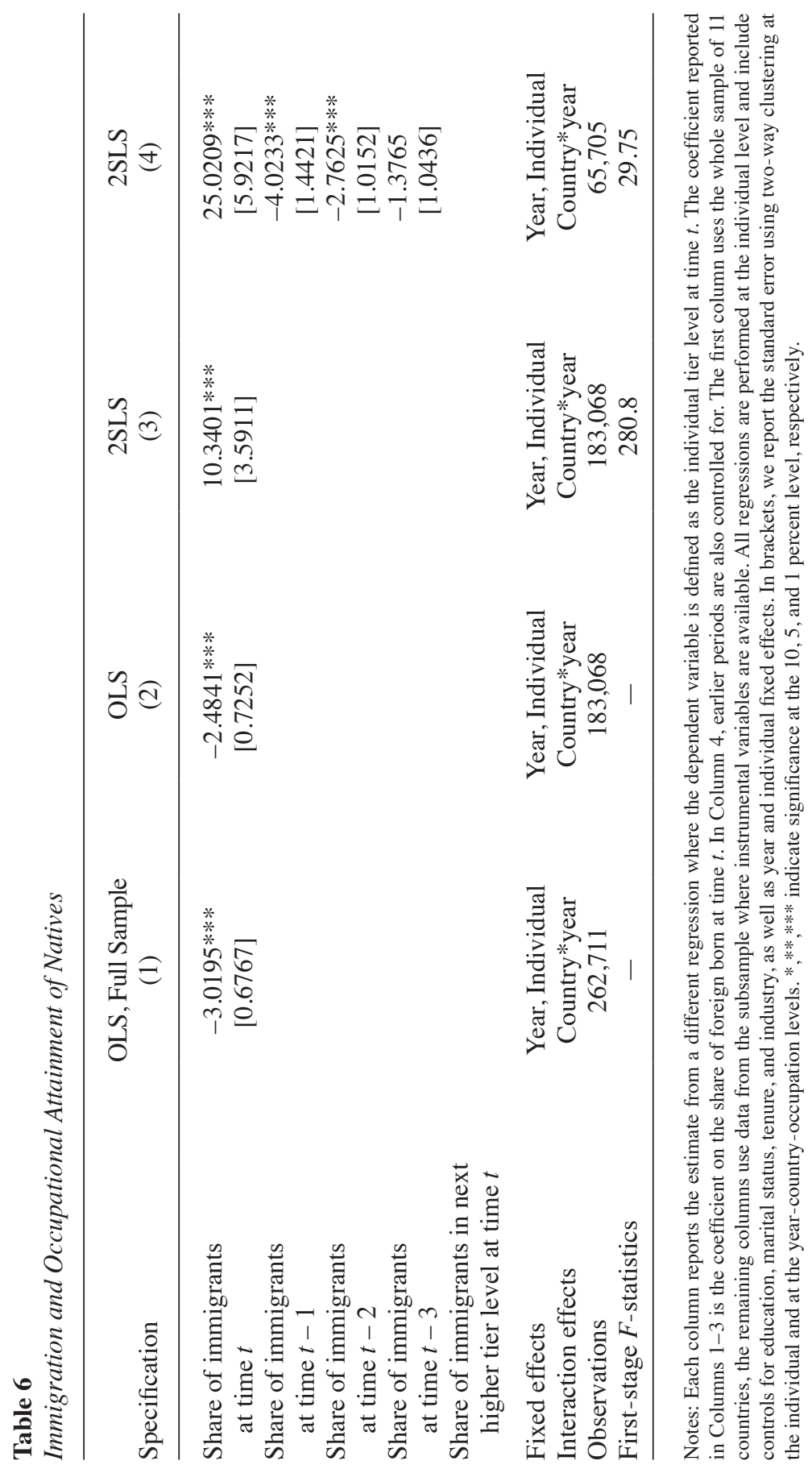


only the result of compositional changes (new hires or selective retirement) but of existing native individuals moving more rapidly toward higher-ranked occupations.

\section{B. Immigrants and Native Unemployment and Wages}

The outcome considered in Table 7 is the unemployment status of native individual $i$ at time $t$. While the mobility toward higher occupational tiers is potentially a positive outcome for natives, it may imply, in the short and medium run, higher risk of unemployment by displacing workers from their initial job. A modified version of the "crowding-out" hypothesis (which argues that immigrants decrease the job opportunities for natives) implies that immigrants push natives to move to other occupations but generate periods of costly unemployment. The fact that natives have to change jobs to take advantage of the opportunities created by immigrants may leave them unemployed or out of the labor force for a while.

To test this possibility, we consider as outcome $y_{i, t}$ a dummy equal to 1 if native individual $i$ is unemployed at time $t$ and 0 if he/she is not. As already discussed in Section IV, we consider only individuals aged 15-65. We then exclude those in education or training, retired, or doing community or military service. Table 7 shows the estimates of the coefficient $\beta$ in such regressions. The table has the same structure as the previous ones, showing different columns with estimates from OLS and 2SLS specifications. The results are similar across specifications and they show no significant effect of immigration on the probability of being unemployed. The point estimates on the share of immigrants at time $t$ in Column 3, with no lags for the immigrant share, are negative and not statistically significant. Also, in the specification that includes the lagged values (Column 4) of the share of immigrants, the coefficients are mostly nonsignificant. If anything, a negative effect of immigration on unemployment emerges for the two-year lag. An increased share of immigrants does not change the natives' likelihood of experiencing unemployment and, with a two-year lag, it may reduce it slightly. This is probably because workers are more likely to be in higher occupational tiers (as shown above) in the following years and the unemployment rate is lower for those occupations. Taken together, these results imply that immigration has no significant impact (or possibly a negative impact after two years) on the probability that a native worker becomes unemployed. This effect is consistent with the hypothesis that immigrants generate complementary working opportunities for natives in higher occupational tiers. They may even induce stronger job creation by firms, stimulating upgrading and employment of natives (as shown, for instance, in Chassamboulli and Palivos 2012). We do not find evidence supporting the idea of crowding out.

Our data also contain information on the yearly wage and salary earnings of an individual. Using these variables, we explore one further potential outcome. First, we analyze the impact of immigrants on yearly wage income of individual natives. On the one hand, the occupational upgrade identified before should contribute positively to wages. On the other, especially in the short run, the loss of specific human capital may offset the positive wage effect of occupational upgrading. Moreover, immigrant competition may decrease the occupational wages at low levels of the occupation ranking so that climbing up may simply offset the potential decreases. Whether immigration in the short run is associated to a positive wage effect on natives is an empirical question.

Table 8 shows that the estimated effect of the foreign-born share on average wages and salaries of natives is positive but not significant at time $t$ for all 2SLS specifications. 


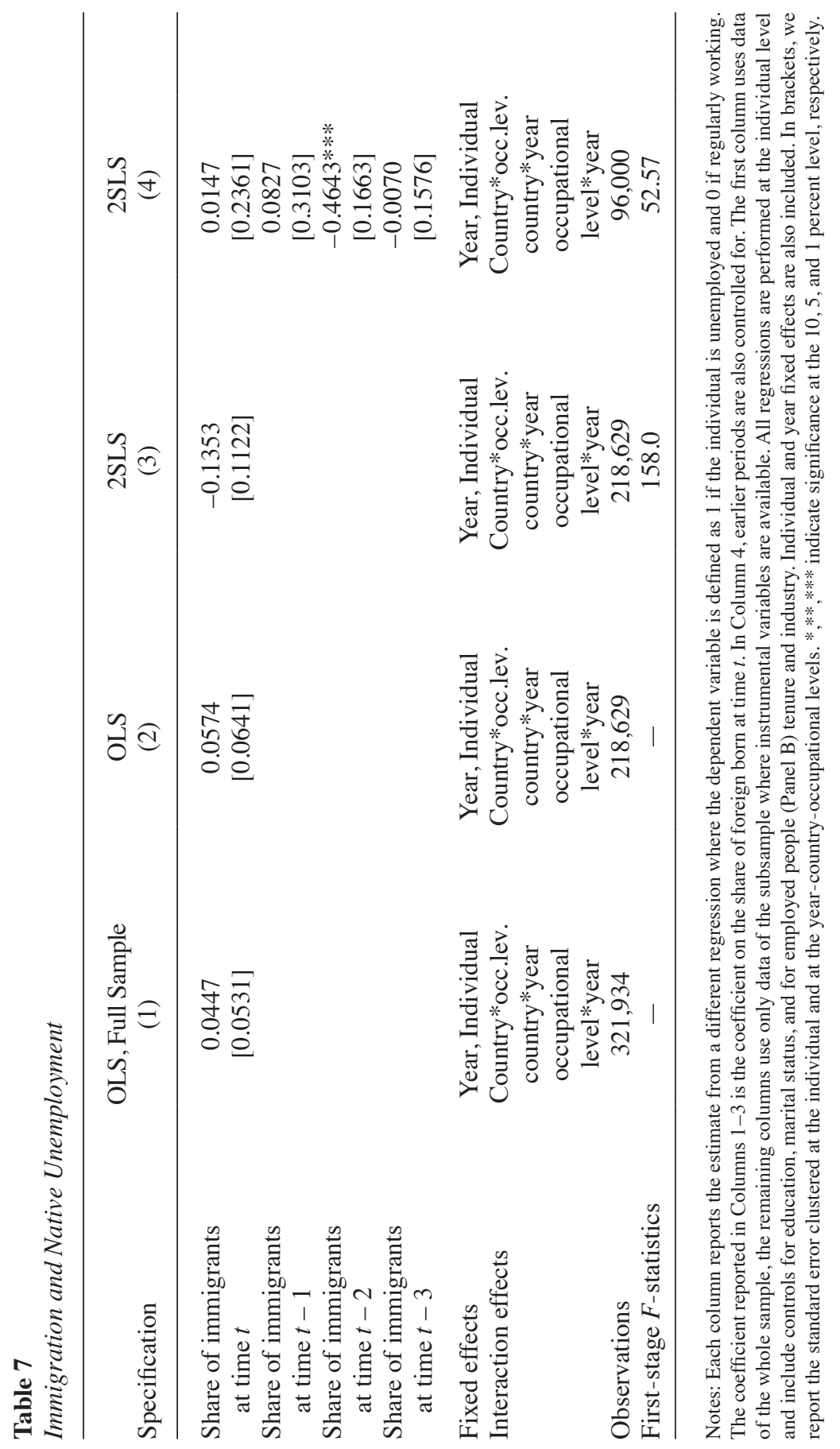




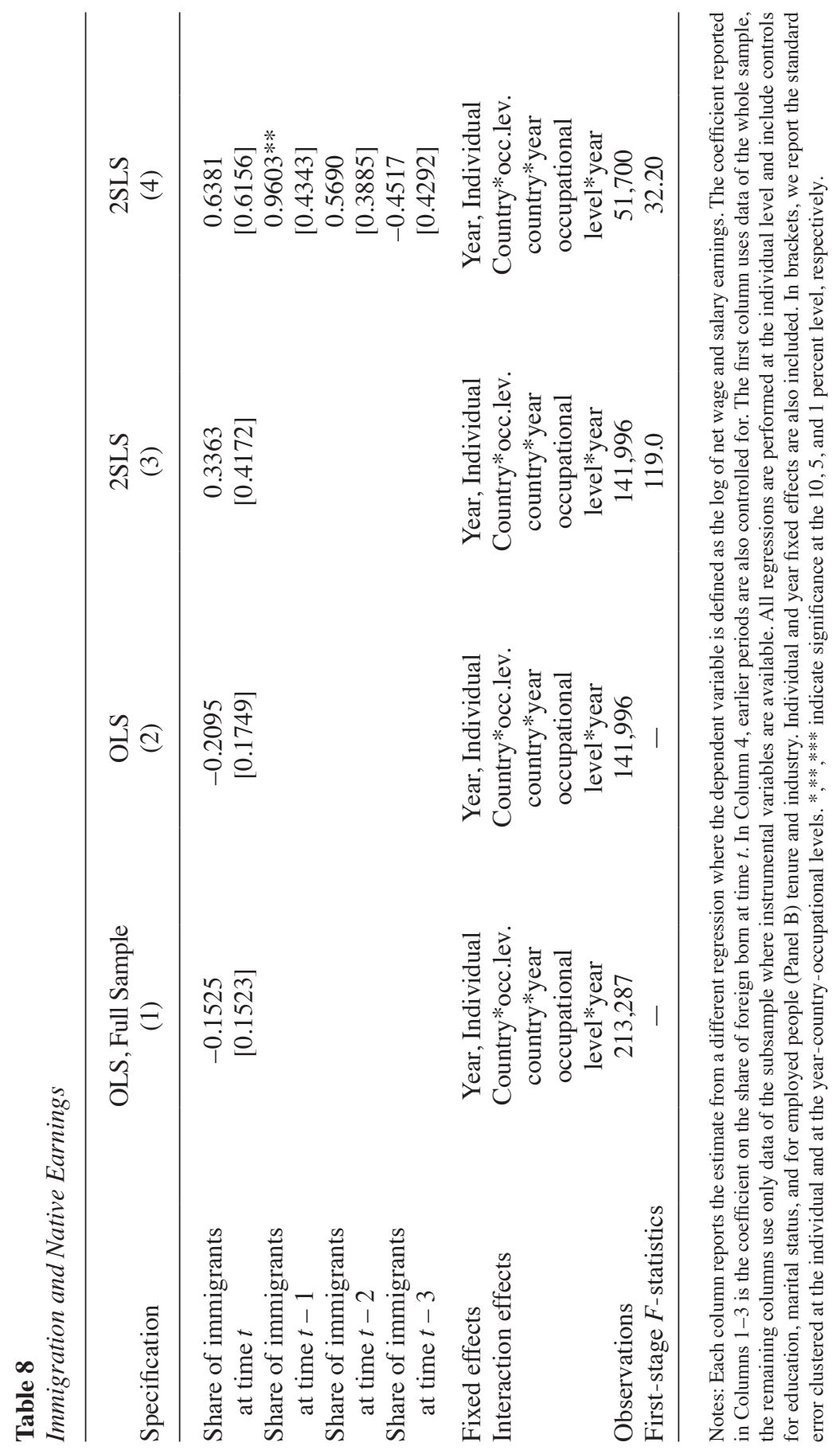


However, the more demanding specification, with the inclusion of the lagged share of immigrants (Column 4), suggests that a significant (but not large) positive effect on natives' wage and salary earnings occurs with one to two-year lags. The point estimates of the effect of immigrants at time $t-1$ is around one. Therefore, an increase of immigrants' share by one standard deviation of cell employment at time $t-1$ would increase the average wage and salary earnings by 4 percent. These results suggest that occupational upgrade may imply a delayed wage increase and no contemporary wage loss. Natives are pushed to a more remunerative occupation, but due to an initial loss of specific human capital the actual wage gain is only shown later. It should be noted that we estimate an average effect, merging people who upgrade with people who do not upgrade. It is possible that the positive effect is driven by the subset of workers upgrading, offsetting possible wage declines of workers who do not upgrade.

\section{Effects on Self-Employment}

We then focus on self-employment income. Self-employment income is a significant component of labor income in many countries. As immigrants usually have a larger self-employment rate than natives, they could have an effect on the employment status of natives. Figure A1 plots the probability of receiving self-employment income for immigrants with respect to natives. Over the period considered, this probability increased sharply. This generated a significant increase in the supply of self-employed immigrants. The response of natives to this change in supply of immigrants can be ambiguous. On the one hand, the presence of immigrants may increase the opportunity of natives to start a business, hiring immigrants in manual tasks at moderate cost. On the other, the competition of immigrants as entrepreneurs can crowd out (pushing toward paid employment) native entrepreneurs. While there are some studies analyzing immigrants as self-employed (Fairlie 2010), there is very little research on whether more immigration encourages natives to become entrepreneurs. An exception is Fairlie and Meyer (2003), which finds a crowding out effect of immigrant entrepreneurs on native ones.

In Table 9, Panel A, we test whether immigration affects an individual's likelihood of receiving no self-employment income, where the outcome variable takes value equal to one if an employed person receives only wage and salary and no self-employment income and 0 if one receives either some or only self-employment income. In Table 9, Panel B, we analyze the effect of immigration on the (logarithm of) self-employment income of natives.

The analysis of these two outcomes provides a sense of the effect on native entrepreneurial activity overall (self-employment income) and on the extensive margin (probability of self-employment). The empirical findings are as follows. First, the likelihood of native workers to receive self-employment income decreases with increased share of foreign born (Table 8, Panel A). An increase of foreign born by one percentage point of cell employment would imply up to 1.1 percentage point increase in the probability of not having any self-employment income. Second, immigration does not produce any significant effect on the average level of self-employment income (Table 9, Panel B). ${ }^{12}$

12. Given the large share of zero self-employment income, one should correct for selection bias. However, as we found no statistically significant effect of the share of immigrants on the log of self-employment income, we did not estimate the same model correcting for selection bias. 
The point estimates, consistent with the result on the extensive margin, are always negative though not statistically significant. This implies a decrease in the propensity to do self-employment activities. Hence, there is some evidence that immigration decreases the probability of self-employment activities by natives and that some crowding-out effects of immigrants on natives occur, consistent in this area with findings by Fairlie and Meyer (2003).

\section{Extension and Checks}

\section{A. Different Definitions of Occupational Mobility}

One key element of our finding is the increased occupational mobility of natives in response to immigration. In order to verify that the specific occupational "tier" structure imposed is not responsible for the findings of larger occupational mobility, in this section we compute occupational change without any occupational level. In particular, we analyze whether immigration affects the probability of natives to move between any of the nine ISCO occupational groups, independently of the direction of this move. We construct a binary outcome variable that we call occupation change. The variable takes the value of 0 for each individual when he/she joins the sample. It equals 1 if individual $i$ works in a different occupation than the initial one while it remains 0 otherwise. This outcome variable does not allow to test for the "direction" of the occupation change but it is a check that immigration affects the propensity of native individuals to change occupation, independently of the tier-structure imposed. Clearly, in the sample there are more occupation changes than the sum of upgrades and downgrades: Some occupation changes are not coded as either upgrades or downgrades as they occur between occupations of the same tier. While the sample average probability of occupational change is 22 percent per year, the sum of average upgrades and downgrades is around 16 percent (see Table A2).

Table 10 presents the empirical findings using occupational change as dependent variable. The point estimate is positive and statistically significant in all 2SLS estimations. The 2SLS coefficients of the share of immigrants at time $t$ are about two when no lags in the share of immigrants are added (Column 3), implying a significant increase in mobility in response to higher immigration. Hence, an increase of immigrants by one standard deviation increases the probability of changing occupation by eight percentage points, from an average of twenty-two to thirty percentage points. The point estimates on occupational change for the 2SLS specifications that include some lags (Column 4) are even larger but imprecisely estimated. These large effects on occupational change suggest that the "net" upgrading effect estimated in Table 4 can be simply the tip of a more pervasive effect on individual "gross" mobility. Besides the net average upgrading effect, there may also be an increase in "horizontal" mobility of natives (specialization) that also contributes to "shield" wages from competition. Overall, immigrants increase the mobility of natives across occupations, which, together with specialization according to comparative advantages, is the key mechanism for the gains from immigration. The results of the previous and of the present section indicate that immigration makes the labor market more dynamic. 


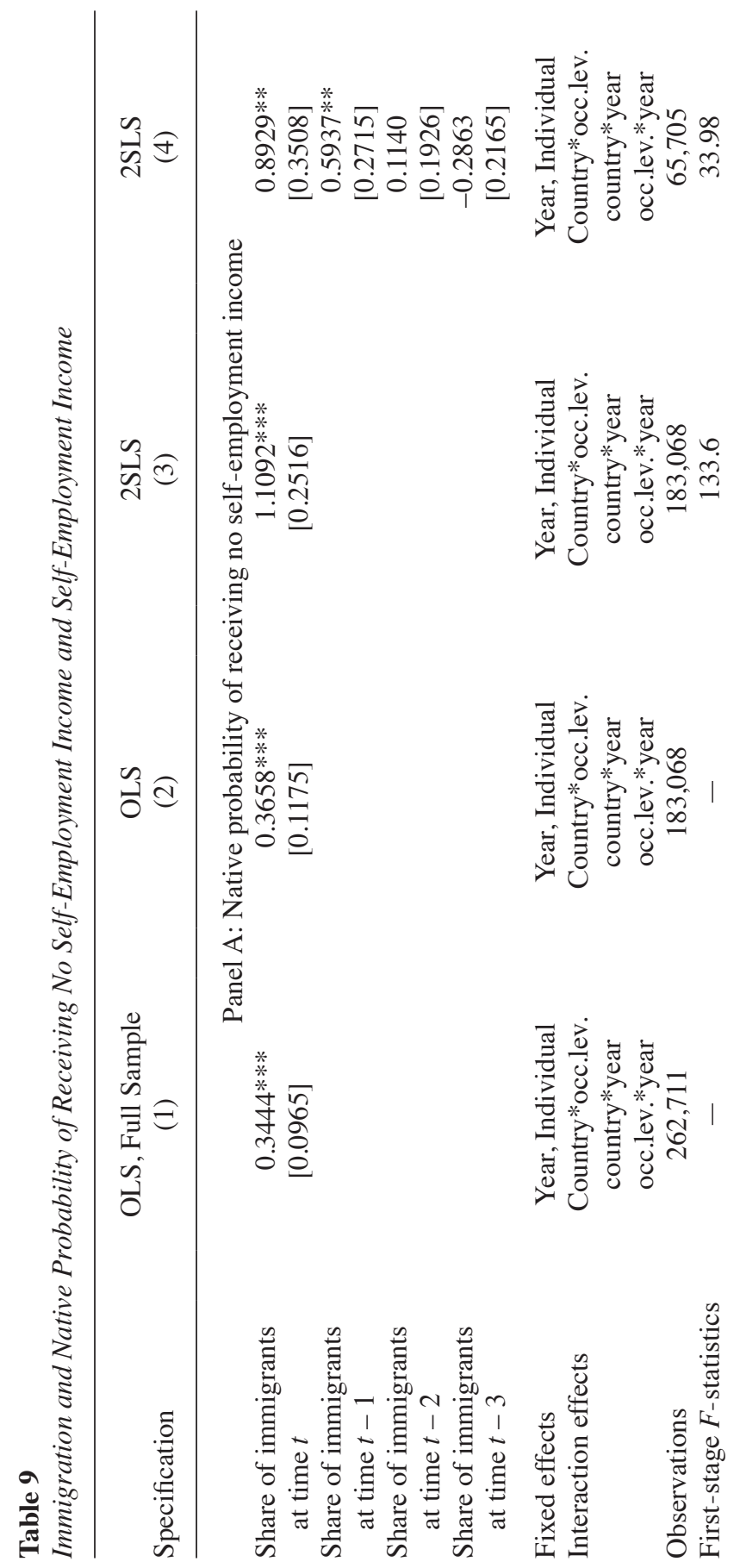



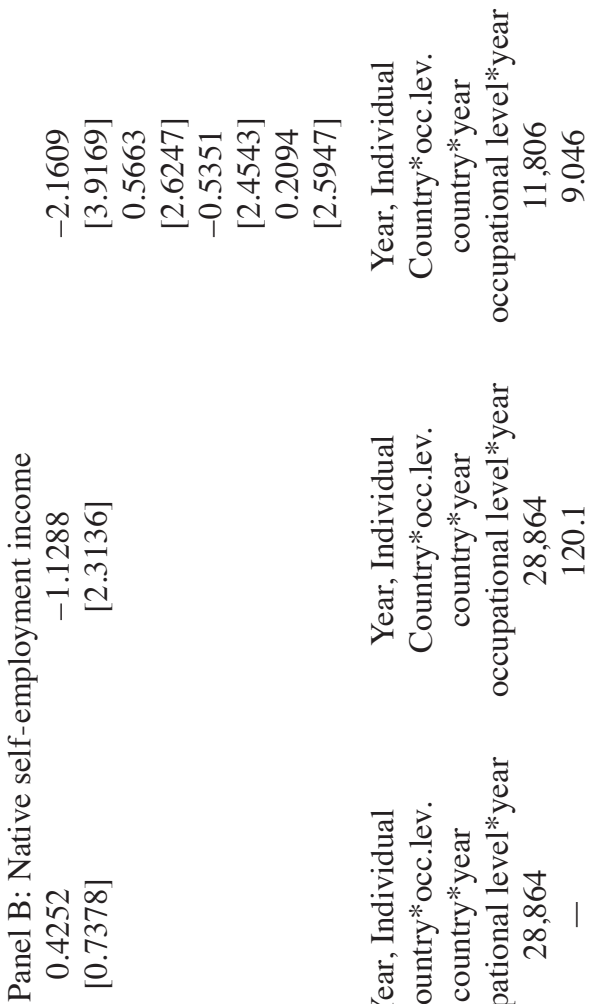

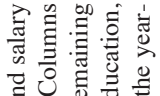

ริ ลูำ inonican .

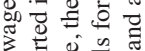
交递完 की 0 क क 0 눙 过范

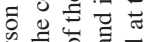

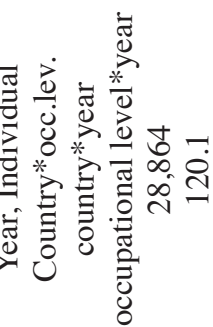

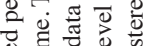
ठิ

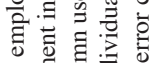

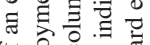

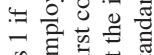

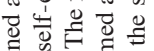
过

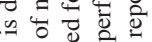
응

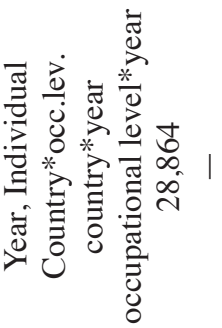

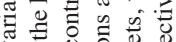

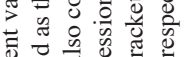

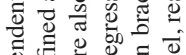

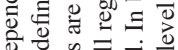
원 过

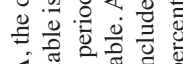

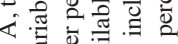

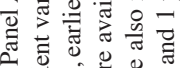

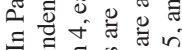

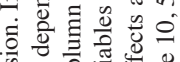

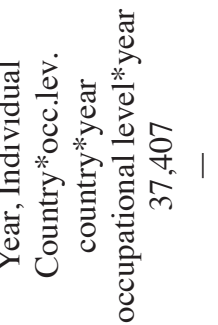

0 웅
$=0$
$=0$
0

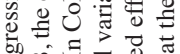

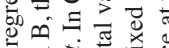

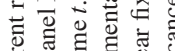

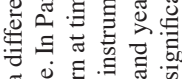

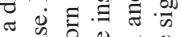

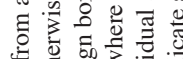

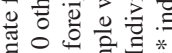
记 ช \&

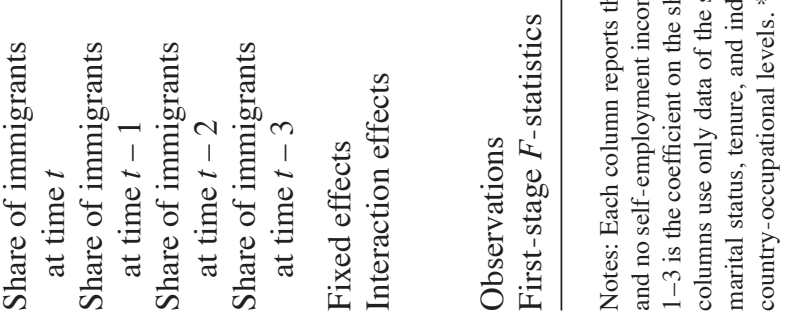




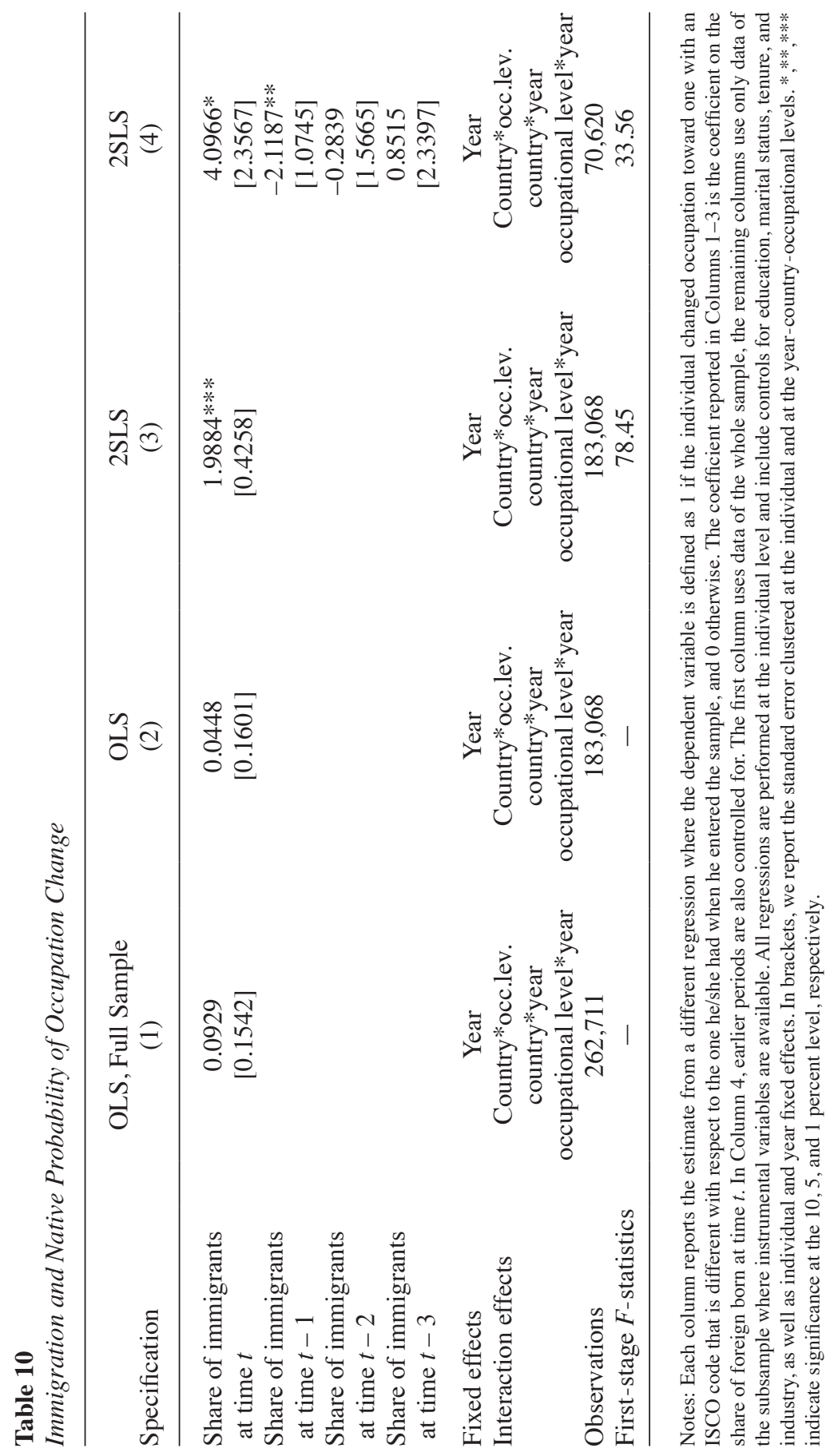




\section{B. Heterogeneity by Initial Skill, Age, Gender}

There is large heterogeneity in the labor market outcomes of workers that is associated to their age, gender, and skills. These differences can make one group more vulnerable and responsive to the inflow of migrants than other groups. In Table 11, we take into account this heterogeneity and we split the sample of workers according to three criteria. First, we distinguish workers in terms of their occupational tiers at the entry in the sample. As we have found a positive effect of the share of immigrants at time $t$ on occupational mobility and occupational attainment, we would like to check whether this also is confirmed by looking at subsamples of workers, depending on their tier when we first observe them in 1995. Native workers in Tier 1 and 2 may be subject to more intense competition from immigrants in manual jobs, whereas natives in Tier 3 may have stronger upward mobility opportunities linked to their higher skills, better ability to learn, and stronger wage incentives to upgrade (as wage distributions are more "stretched" at the top). Second, we assess whether the ability to respond to immigration via an occupational upgrade is mainly an opportunity for young workers, defined as individuals younger than age 40 at the entry in the sample, or if it is also shown by older workers. Third, we also test whether results are robust to the exclusion of individuals younger than 25 . This group could include workers who are also enrolled in higher education and who may experience large upgrades after the completion of their tertiary education. Finally, we distinguish between male and female workers. A larger share of immigrants in Europe is male so one could expect a larger pressure on that gender to upgrade occupation. However, some house-service occupations typical of migrants can substitute for women's household work. All these models are estimated by 2 SLS using Specification 1, which does not include the lagged values of immigrant share.

The empirical findings presented in Table 11 show the estimated effect of immigrants on occupational mobility (Panel A), unemployment status (Panel B), and log earnings (Panel C). First, Columns 1 and 2 show that workers both in lower and upper tiers are significantly more likely to experience occupational upward mobility as a consequence of immigrant competition. The coefficient is larger for workers starting at high tiers, suggesting more responsiveness of intermediate occupations to immigration waves. As for occupational attainment, results show positive coefficients for both groups, which are only statistically significant for the group in the upper tiers. These results are consistent with the hypothesis that large inflows of immigrants increase the demand for managerial occupations and natives have a particular advantage in those. In Columns 3 and 4, we present results for the group of young workers (younger than 40 years old) and older workers (40 years or older). Occupational mobility induced by immigrant inflows occurs more strongly among older natives than younger ones. The point estimates in both the occupational mobility and the occupational attainment specifications are larger for natives older than 40 years than for those younger than 40 years. This result may be linked to the fact that older workers have higher probability of being in Tier 3, which is where most upward mobility in response to immigrants takes place. The possibility of having access to managerial occupations and the presence of complementary immigrants in the lower tier may accelerate that process.

Column 5 presents results for workers 25 years or older, representing workers notin-education age. The point estimates are in line with the results of the main regressions 


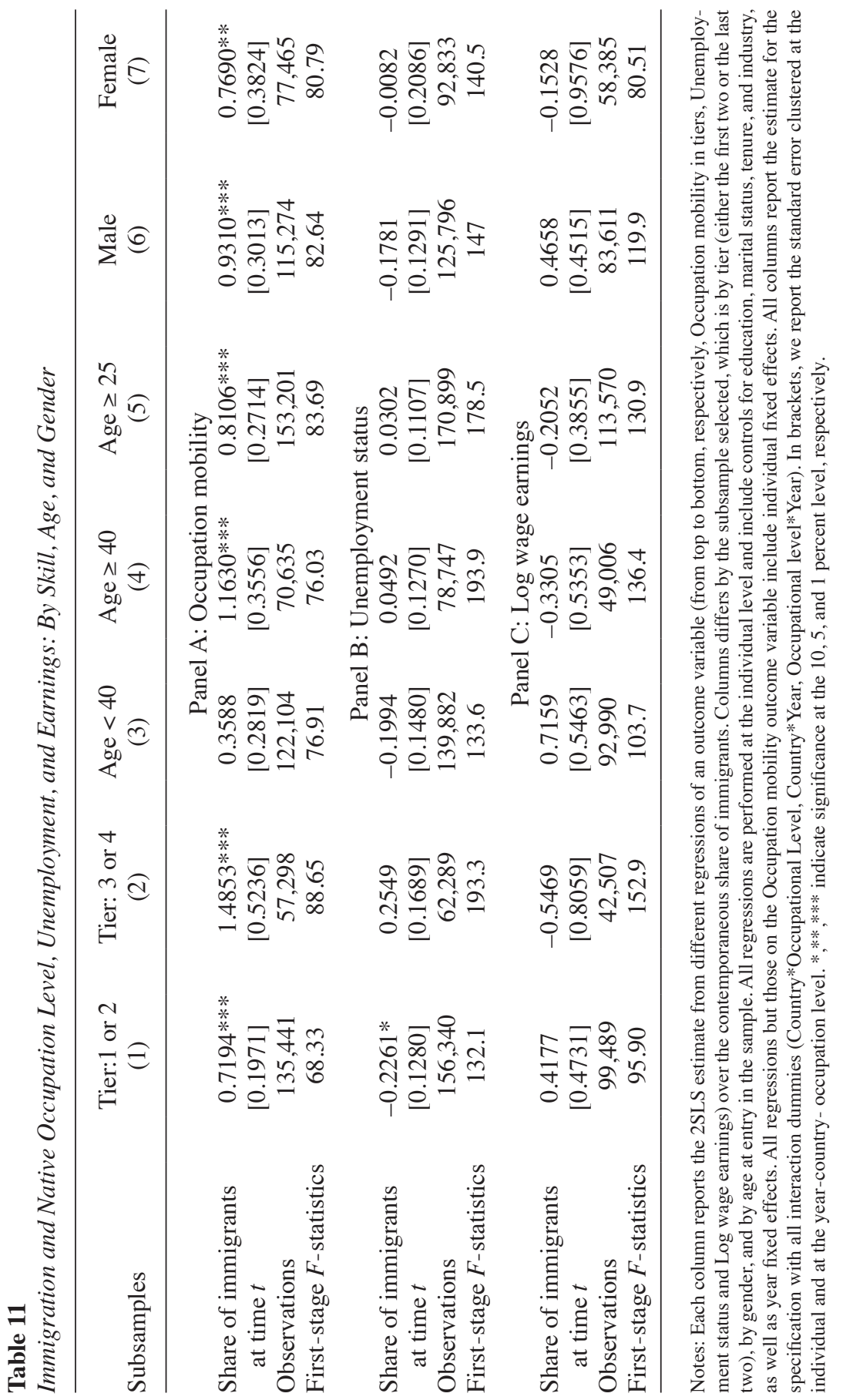


(recall Table 3). This finding indicates that the upgrade induced by immigration is not the result of increases in graduation probability boosted by the presence of immigrants. The impact of immigrants on schooling attainment of natives (Hunt 2012) could be a form of "upgrading" but it is not the mechanism driving our results.

Columns 6 and 7 present the results for the male and female subsamples, respectively. Both subgroups show significantly positive estimated coefficients for occupation level mobility and attainment. Therefore, not only male but also female workers are positively influenced by immigrant inflows. This may indicate that immigrants substitute for manual house services typically employing females (house cleaning, babysitting, elder care), and this may allow native females to be employed in more professional roles and enjoy more dynamic careers (Cortes and Tessada 2011).

The impact on unemployment status, shown in the middle section of Table 11, suggests that the probability of unemployment of natives is not an outcome affected by immigration for any of the groups considered. In fact, for individuals beginning at Tier 1 or 2, a larger inflow of immigrants in their markets decreases the probability of unemployment. Be it because of the immigrant-native complementarity or because firms increase job creation when immigration is large, we do not observe evidence in the EU of immigrants crowding out natives. Similarly, the contemporaneous effects of immigrants on wages is negligible for all groups. Remember that in Table 8 we found some lagged positive effects of immigration on wages but no significant contemporaneous effects.

\section{Conclusions}

In this paper, we have analyzed the impact of immigration on several native outcomes. The novelty of the approach is that we use data that allow us to follow native individuals in a panel and analyze the response in their working careers after they have been exposed to labor market competition from immigrants. Our main focus is to analyze whether the exposure to immigrant competition accelerates or slows the career of native workers. Using the presence of immigrants from different nationalities in 1991 in country-occupation cells in Europe and their inflow during the period 1995-2001, we compare natives exposed to large or small waves of immigrant competition and we use this variation to identify the effects on their career.

We find that immigrant competition increases the probability of upward mobility of natives within the observed period. Also, interestingly, we find that a faster mobility did not take place at the cost of higher probability of unemployment. The dynamic effects of immigration, in fact, did not imply that natives were crowded out but instead that working opportunities were created in higher occupation levels. If anything, the lagged impact of immigrants on unemployment was negative. It is possible that foreigners, by taking jobs complementary to those of natives, induce stronger job creation by firms. The upward mobility seems stronger among females and among natives starting at intermediate occupational levels (rather than from very low levels). Native individuals are also more likely to leave self-employment in response to immigrant competition and, in general, immigration increases substantially occupational mobility of natives.

Our findings are unique in that we follow a representative panel of European workers and control for their observed and unobserved (time-invariant) characteristics. 
Hence, different from the previous literature, issues of selection, unobserved heterogeneity, and attrition of native workers do not bias our results. We isolate the causal impact of immigrants on native individuals exposed to competition from immigrants. The impact of an immigration shock on native careers is a new dimension of analysis of the labor market effects of immigrants and may have very important long-run implications for the gains from immigration.

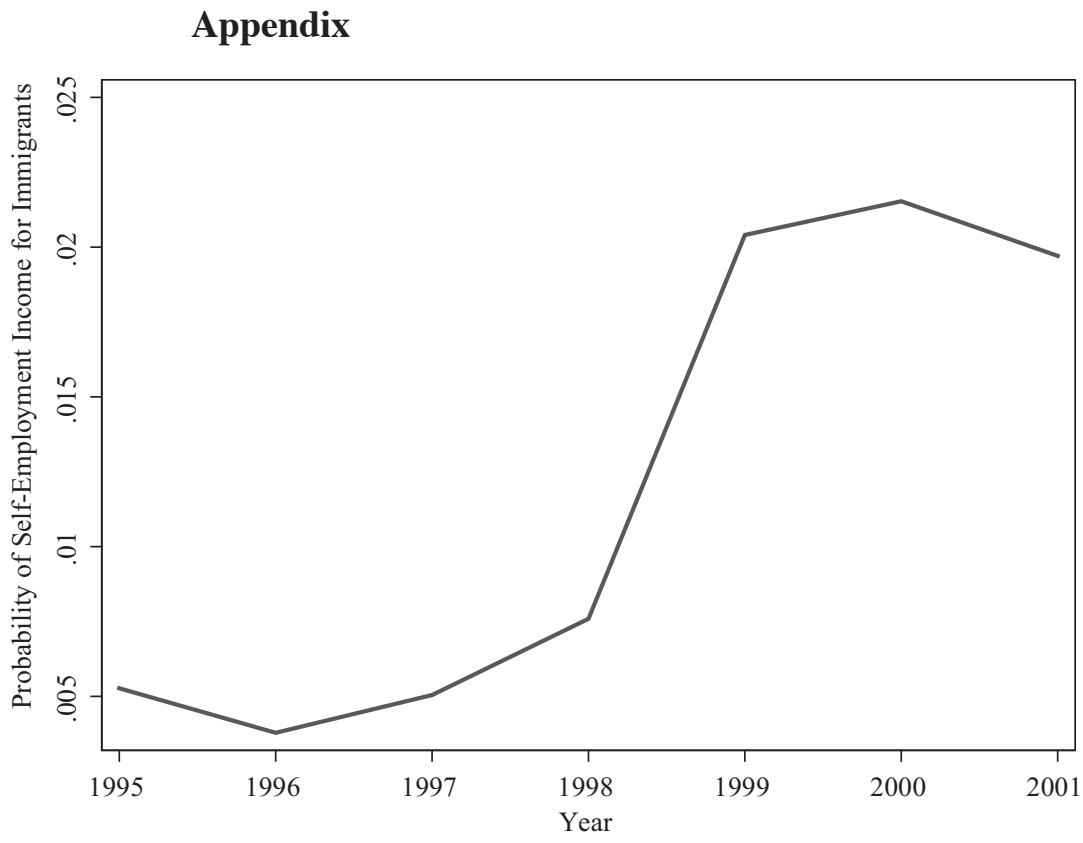

\section{Figure A1}

Probability of Receiving any Self-Employment Income for Immigrants with Respect to Natives

Notes: This line plots the pointwise estimates of the simple correlations between the probability of receiving any self-employment income and foreign-born dummies: $y_{i t}=\vartheta_{i}+\vartheta_{t}+\vartheta_{f t}+\varepsilon_{i t}$, where $y_{i t}$ is coded 1 if individual $i$ receives any self-employment income and 0 otherwise, $\vartheta_{f t}$ is the interaction between a foreign-born dummy and year fixed effects, $\vartheta_{i}$ and $\vartheta_{t}$ are individual and year fixed effects, respectively. Estimates are obtained by OLS over the full sample of natives and immigrants and errors are clustered at the individual level. 


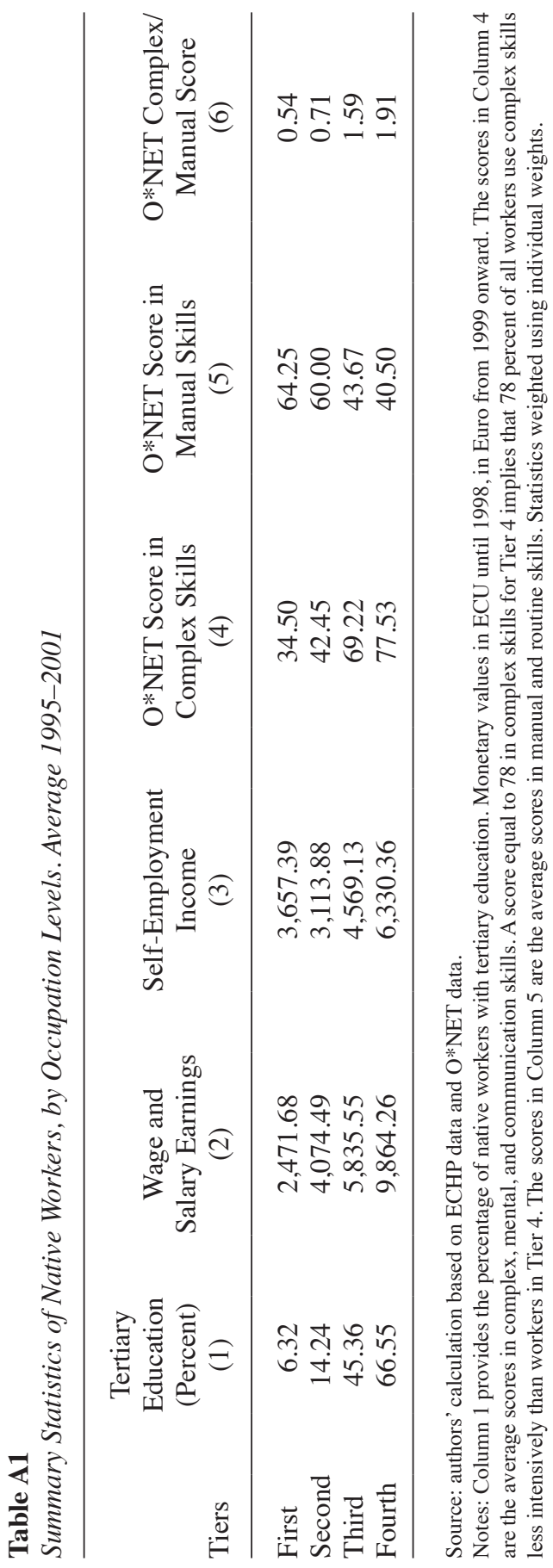


Table A2

Summary Statistics of the Main Variables for Natives Only from ECHP. IndividualYear Observations, Average 1995-2001.

\begin{tabular}{lrrr}
\hline Variable & & & Standard \\
& Observations & Mean & Deviation \\
\hline Full sample & & & \\
Occupation mobility (tier) & 262,711 & 0.0274 & 0.4091 \\
Occupation upgrade mobility (tier) & 262,711 & 0.0977 & 0.2970 \\
Occupation downgrade mobility (tier) & 262,711 & 0.0704 & 0.2558 \\
Occupation attainment (tier) & 262,711 & 2.5012 & 0.9279 \\
Unemployment status & 321,934 & 0.0484 & 0.2146 \\
Log-wage income & 213,287 & 9.3161 & 0.8660 \\
Log self-employment income & 37,407 & 8.7656 & 1.3752 \\
No self-employment income & 262,711 & 0.7899 & 0.4074 \\
Occupation change (occupation level) & 262,711 & 0.2311 & 0.4215 \\
Share of immigrants at time $t$ & 262,711 & 0.0558 & 0.0370 \\
2SLS sample & & & \\
Occupation mobility (tier) & 183,068 & 0.0193 & 0.3952 \\
Occupation upgrade mobility (tier) & 183,068 & 0.0879 & 0.2832 \\
Occupation downgrade mobility (tier) & 183,068 & 0.0686 & 0.2528 \\
Occupation attainment (tier) & 183,068 & 2.4143 & 0.9024 \\
Unemployment status & 218,629 & 0.0546 & 0.2273 \\
Log-wage income & 141,996 & 9.1761 & 0.8635 \\
Log self-employment income & 28,864 & 8.6989 & 1.3130 \\
No self-employment income & 183,068 & 0.7617 & 0.4260 \\
Occupation change (occupation level) & 183,068 & 0.2196 & 0.4140 \\
Share of immigrants at time $t$ & 183,068 & 0.0566 & 0.0397 \\
\hline
\end{tabular}

Source: authors' calculation based on ECHP data.

Notes: Monetary values in ECU until 1998, in Euros from 1999 onward.

\section{Table A3}

One-Year Mobility of Native Workers Across the Four Occupation Tiers (Percent). Average 1995-2001

Tier at Time $t$

\begin{tabular}{lrrrrr}
\cline { 2 - 5 } Tier at Time $t-1$ & First & Second & Third & Fourth & All \\
\hline First & 78.52 & 19.03 & 1.36 & 1.09 & 100 \\
Second & 2.59 & 92.41 & 2.65 & 2.35 & 100 \\
Third & 0.60 & 8.61 & 83.50 & 7.29 & 100 \\
Fourth & 0.34 & 5.30 & 4.29 & 90.07 & 100 \\
All & 8.71 & 55.81 & 14.47 & 21.01 & 100 \\
\hline
\end{tabular}

Source: authors' calculation based on ECHP data. 


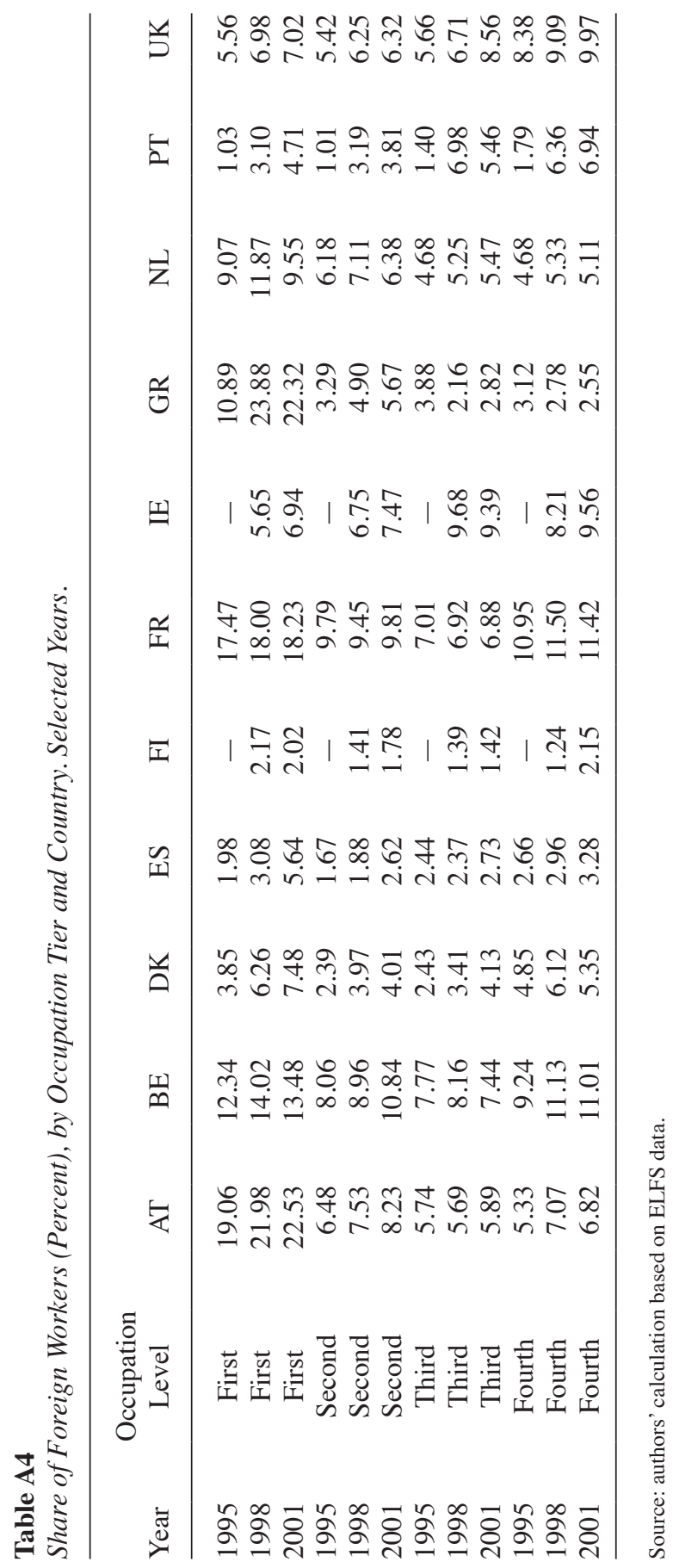




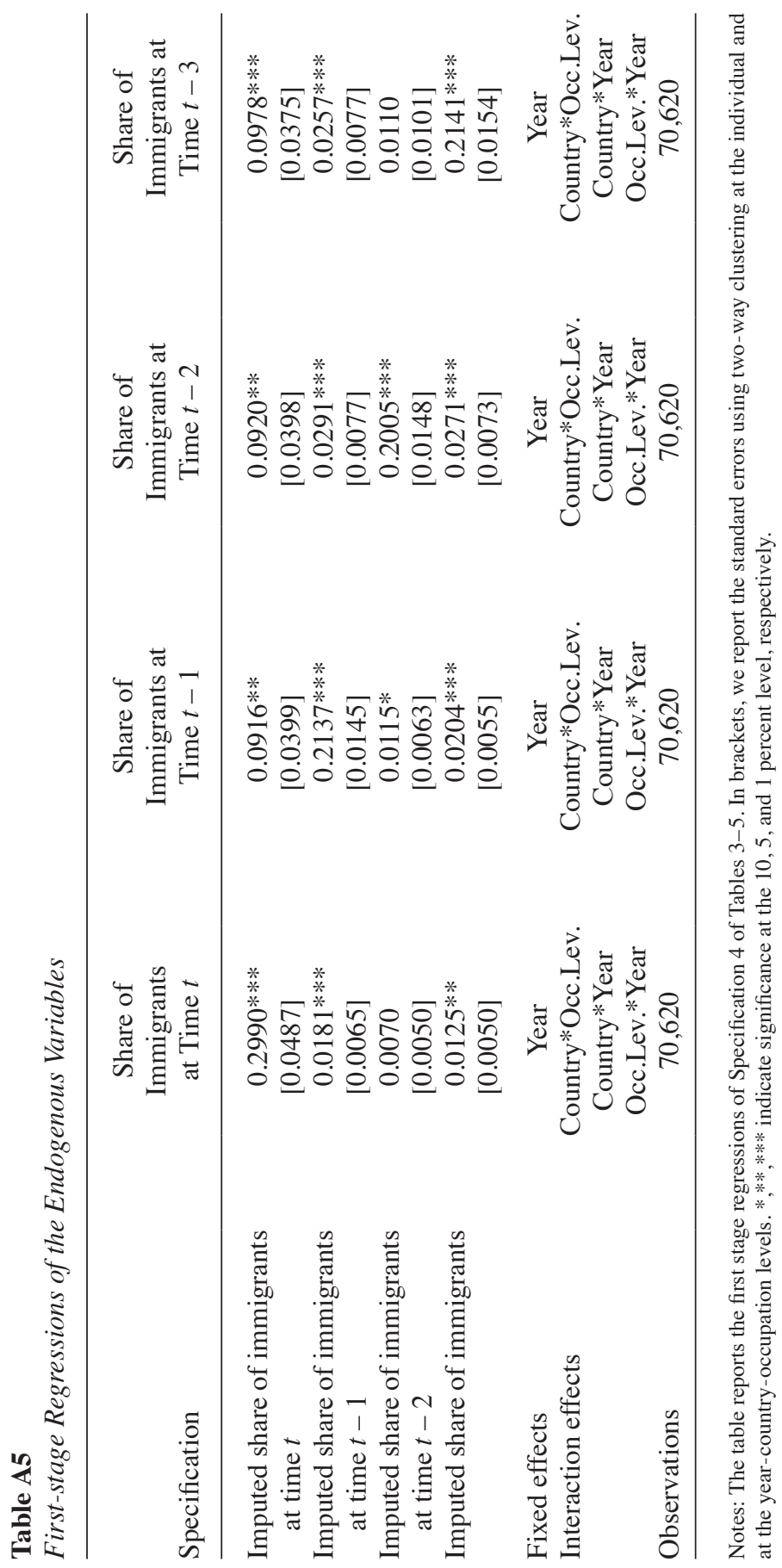




\section{Table A6}

First-stage Regressions of the Endogenous Variables

\begin{tabular}{|c|c|c|}
\hline Specification & $\begin{array}{l}\text { Share of } \\
\text { Immigrants } \\
\text { at Time } t\end{array}$ & $\begin{array}{l}\text { Share of } \\
\text { Immigrants in } \\
\text { Next Higher Tier } \\
\text { Level at Time } t\end{array}$ \\
\hline $\begin{array}{l}\text { Imputed share of immigrants } \\
\text { at time } t\end{array}$ & $\begin{array}{l}0.3402 * * * \\
{\left[\begin{array}{ll}0 & .0374]\end{array}\right.}\end{array}$ & $\begin{array}{l}0.3358 * * * \\
{[0.0605]}\end{array}$ \\
\hline $\begin{array}{l}\text { Imputed share of immigrants in } \\
\text { next higher tier level at time } t\end{array}$ & $\begin{array}{l}0.0556 * * * \\
{[0.0103]}\end{array}$ & $\begin{array}{l}0.2831 * * * \\
{[0.0191]}\end{array}$ \\
\hline Fixed effects & Year & Year \\
\hline Interaction effects & $\begin{array}{c}\text { Country*Occ.Lev. } \\
\text { Country*Year } \\
\text { Occ.Lev.*Year } \\
70,620\end{array}$ & $\begin{array}{c}\text { Country*Occ.Lev. } \\
\text { Country*Year } \\
\text { Occ.Lev.*Year } \\
70,620\end{array}$ \\
\hline
\end{tabular}

Notes: The table reports the first-stage regressions of Specification 5 of Tables 3-5. In brackets, we report the standard errors using two-way clustering at the individual and at the year-country-occupation levels. $*, * *, * * *$ indicate significance at the 10,5 , and 1 percent level, respectively.

\section{References}

Altonji, Joseph, and David Card. 1991. "The Effects of Immigration on the Labor Market Outcomes of Less-Skilled Natives." In Immigration, Trade and the Labor Market, ed. John Abowd and Richard Freeman, 201-34. National Bureau of Economic Research, Inc. Chicago: University of Chicago Press.

Bartel, Ann, and Sicherman Nachum. 1998. "Technological Change and the Skill Acquisition of Young Workers." Journal of Labor Economics 16(4):718-55.

Borjas, George. 2003. "The Labor Demand Curve Is Downward Sloping: Reexamining the Impact of Immigration on the Labor Market." Quarterly Journal of Economics 118(4):1335-74.

- 2006. "Native Internal Migration and the Labor Market Impact of Immigration." Journal of Human Resources 41(2):221-58.

Borjas, George, Jeffrey Grogger, and Gordon Hanson. 2008. "Imperfect Substitution Between Immigrants and Natives: A Reappraisal." NBER Working Paper 13887.

Card, David. 2001. "Immigrant Inflows, Native Outflows, and the Local Labor Market Impacts of Higher Immigration." Journal of Labor Economics 19(1):22-64.

. 2009. "Immigration and Inequality." American Economic Review 99(2):1-21.

Card, David, and John DiNardo. 2000. "Do Immigrant Inflows Lead to Native Outflows?" American Economic Review 90(2):360-67.

Chassamboulli, Andri, and Theodore Palivos. 2012. "A Search-Equilibrium Approach to the Effects of Immigration on Labor Market Outcomes.” Working Papers in Economics 17-2012, University of Cyprus Department of Economics, Nicosia.

Cohen-Goldner, Sarit, and Daniele Paserman. 2011. "The Dynamic Impact of Immigration on Natives' Labor Market Outcomes: Evidence from Israel.” European Economic Review 55(8):1027-45. 
Cortes, Patricia, and Jose Tessada. 2011. "Low-Skilled Immigration and the Labor Supply of Highly Skilled Women." American Economic Journal: Applied Economics 3(3):88-123.

D'Amuri, Francesco, Gianmarco Ottaviano, and Giovanni Peri. 2010. "The Labor Market Impact of Immigration in Western Germany in the 1990s." European Economic Review 54(4):550-70.

D'Amuri, Francesco, and Giovanni Peri. 2014. "Immigration, Jobs and Employment Protection: Evidence from Europe Before and During the Great Recession." Journal of the European Economic Association 12(2):432-64.

Dunne, Timothy, Lucia Foster, John Haltiwanger, and Kenneth R. Troske. 2004. "Wage and Productivity Dispersion in United States Manufacturing: The Role of Computer Investment." Journal of Labor Economics 22(2):397-430.

Dustmannn, Christian, Tommaso Frattini, and Ian Preston. 2013. "The Effect of Immigration Along the Distribution of Wages." Review of Economic Studies 80(1):145-73.

Elias, Peter, and Abigail McKnight. 2001. "Skill Measurement in Social Statistics: Recent Developments in the UK and the Rest of Europe." Oxford Economic Papers 53(3):508-40.

European Commission. 1996. European Community Household Panel (EHCP): Volume 1 Survey Methodology and Implementation. Office for Official Publications of the European Communities, Luxembourg.

Eurostat. 2009. European Union Labour Force Survey Database. User guide.

Fairlie, Robert. 2010. "Mexican American Entrepreneurs and Their Contribution to the U.S. Economy." In Open for Business: Migrant Entrepreneurs in OECD Countries, 213-25. Paris: OECD Publishing.

Fairlie, Robert, and Bruce D. Meyer. 2003. "The Effects of Immigration on Native SelfEmployment." Journal of Labor Economics 21(3):619-50.

Foged, Mette, and Giovanni Peri. 2013. "Immigrants and Native Workers: New Analysis Using Longitudinal Employer-Employee Data.” NBER Working Paper 19315.

Glitz, Albrecht. 2012. "The Labor Market Impact of Immigration: A Quasi-Experiment Exploiting Immigrant Location Rules in Germany." Journal of Labor Economics 30(1):175213.

Hunt, Jennifer. 2012. "The Impact of Immigration on the Educational Attainment of Natives." NBER Working Paper 18047.

ILO. 1990. ISCO-88: International Standard Classification of Occupations. Technical Report, ILO Geneva.

Kerr, William, and Saari Pekkala Kerr. 2013. "Immigration and Employer Transition for STEM Workers." American Economic Review 103(3):193-97.

Lewis, Ethan. 2011. "Immigration, Skill Mix, and Capital-Skill Complementarity." Quarterly Journal of Economics 126(2):1029-69.

Neal, Derek. 1995. "Industry-Specific Human Capital: Evidence from Displaced Workers." Journal of Labor Economics 13(4):653-77.

Oreopoulos, Phillip, Till von Wachter, and Andrew Heisz. 2012. "The Short- and Long-Term Career Effects of Graduating in a Recession." American Economic Journal: Applied Economics 4(1):1-29.

Ottaviano, Gianmarco, and Giovanni Peri. 2012. "Rethinking the Effect of Immigration on Wages." Journal of the European Economic Association 10(1):152-97.

Peracchi, Franco. 2002. "The European Community Household Panel: A Review.” Empirical Economics 27(1):63-90.

Peri, Giovanni, and Chad Sparber. 2009. "Task Specialization, Immigration, and Wages." American Economic Journal: Applied Economics 1(3):135-69.

— 2011. "Highly-Educated Immigrants and Native Occupational Choice." Industrial Relations 50(3):385-411. 
Stevens, Ann Huff. 1997. "Persistent Effects of Job Displacement: The Importance of Multiple Job Losses." Journal of Labor Economics 15(1):165-88.

Von Wachter Till, Jae Song, and Joyce Manchester. 2007. "Long-Term Earnings Losses Due to Job Separation During the 1982 Recession: An Analysis Using Longitudinal Administrative Data from 1974 to 2004." Discussion Paper 0708-16, Columbia University, Department of Economics.

Zoghi, Cindy, and Sabrina Wulff Pabilonia. 2007. "Which Workers Gain upon Adopting a Computer?" Canadian Journal of Economics 40(2):423-44. 